\title{
Sodium Channel $\beta 2$ Subunits Regulate Tetrodotoxin- Sensitive Sodium Channels in Small Dorsal Root Ganglion Neurons and Modulate the Response to Pain
}

\author{
Luis F. Lopez-Santiago, ${ }^{1}$ Marie Pertin, ${ }^{2,3}$ Xavier Morisod, ${ }^{2,3}$ Chunling Chen, ${ }^{1}$ Shuangsong Hong, ${ }^{4}$ John Wiley, ${ }^{4}$ \\ Isabelle Decosterd, ${ }^{2,3 \star}$ and Lori L. Isom ${ }^{1 \star}$ \\ ${ }^{1}$ Department of Pharmacology, University of Michigan, Ann Arbor, Michigan 48109-0632, ${ }^{2}$ Anesthesiology Pain Research Group, Anesthesiology \\ Department, Lausanne University Hospital (Centre Hospitalier Universitaire Vaudois), CH-1011 Lausanne, Switzerland, ${ }^{3}$ Department of Cell Biology and \\ Morphology, Faculty of Biology and Medicine, University of Lausanne, CH-1005 Lausanne, Switzerland, and ${ }^{4}$ Department of Internal Medicine and General \\ Clinical Research Center, University of Michigan, Ann Arbor, Michigan 48109-0108
}

Voltage-gated sodium channel $\left(\mathrm{Na}_{\mathrm{v}} 1\right) \beta 2$ subunits modulate channel gating, assembly, and cell-surface expression in CNS neurons in vitro and in vivo. $\beta 2$ expression increases in sensory neurons after nerve injury, and development of mechanical allodynia in the spared nerve injury model is attenuated in $\beta 2$-null mice. Thus, we hypothesized that $\beta 2$ modulates electrical excitability in dorsal root ganglion (DRG) neurons in vivo. We compared sodium currents $\left(I_{\mathrm{Na}}\right)$ in small DRG neurons from $\beta 2^{+/+}$and $\beta 2^{-/-}$mice to determine the effects of $\beta 2$ on tetrodotoxin-sensitive (TTX-S) and tetrodotoxin-resistant (TTX-R) $\mathrm{Na}_{\mathrm{v}} 1$ in vivo. Small-fast DRG neurons acutely isolated from $\beta 2^{-l-}$ mice showed significant decreases in TTX-S $I_{\mathrm{Na}}$ compared with $\beta 2^{+/+}$neurons. This decrease included a $51 \%$ reduction in maximal sodium conductance with no detectable changes in the voltage dependence of activation or inactivation. TTX-S, but not TTX-R, $\mathrm{I}_{\mathrm{Na}}$ activation and inactivation kinetics in these cells were slower in $\beta 2^{-l-}$ mice compared with controls. The selective regulation of TTX-S $I_{\mathrm{Na}}$ was supported by reductions in transcript and protein levels of TTX-S $\mathrm{Na}_{\mathrm{v}} 1 \mathrm{~s}$, particularly $\mathrm{Na}_{\mathrm{v}}$ 1.7. Low-threshold mechanical sensitivity was preserved in $\beta 2^{-I-}$ mice, but they were more sensitive to noxious thermal stimuli than wild type whereas their response during the late phase of the formalin test was attenuated. Our results suggest that $\beta 2$ modulates TTX-S $\mathrm{Na}_{\mathrm{v}} 1 \mathrm{mRNA}$ and protein expression resulting in increased TTX-S $\mathrm{I}_{\mathrm{Na}}$ and increases the rates of TTX-S $\mathrm{Na}_{\mathrm{v}} 1$ activation and inactivation in small-fast DRG neurons in vivo. TTX-R $\mathrm{I}_{\mathrm{Na}}$ were not significantly modulated by $\beta 2$.

Key words: sodium channel; $\beta$ subunit; dorsal root ganglion; tetrodotoxin sensitive; nociception; mouse

\section{Introduction}

$\mathrm{Na}_{\mathrm{v}} 1$ s are composed of a central, pore-forming $\alpha$ subunit and one or two $\beta$ subunits that modulate channel expression levels, voltage dependence, and kinetics (Catterall, 2000). $\beta 1, \beta 1 \mathrm{~A}, \beta 2, \beta 3$, and $\beta 4$ subunits regulate channel gating, assembly, and cellsurface expression in vitro (Goldin, 1993; Isom et al., 1994; Isom, 2000; Yu et al., 2003; McEwen et al., 2004). $\beta 1$ and $\beta 2$ also participate in homophilic (Malhotra et al., 2000) and/or heterophilic (Ratcliffe et al., 2001; Kazarinova-Noyes et al., 2001; McEwen et al., 2004) cell adhesion. $\beta 1$ and $\beta 2$ can also interact with extracellular matrix molecules (Srinivasan et al., 1998; Xiao et al.,

\footnotetext{
Received Jan. 26, 2006; revised June 20, 2006; accepted June 21, 2006.

This work was supported by National Multiple Sclerosis Society Research Grant RG-2882 (L.L.I.), Michigan Life Sciences Corridor Grant 001654 (L.L.I.), Gastrointestinal Peptide Research (enter of the University of Michigan Grant 2P30DK34933 (L.F.L.-S.), National Institutes of Health Grant R01DK056997 (J.W.), Swiss National Science Foundation Grant 31000-112577 (I.D.), and the Pierre Mercier Science Foundation (I.D.). We thank Heather O'Malley, Audrey Speelman, Anne-Frederique Bourquin, and Temugin Berta for expert technical assistance and Dr. Kathryn E. Rogers for helpful scientific discussions.

*I.D. and L.L.I. contributed equally to this work.

Correspondence should be addressed to Dr. Lori L. Isom, Department of Pharmacology, University of Michigan, 1301 MSRB III, 1150 West Medical Center Drive, Ann Arbor, MI 48109-0632. E-mail: lisom@umich.edu. DOI:10.1523/JNEUROSCI.2211-06.2006

Copyright $\odot 2006$ Society for Neuroscience $\quad$ 0270-6474/06/267984-11\$15.00/0
}

1999), ankyrin (Srinivasan et al., 1988, 1998; Xiao et al., 1999; Malhotra et al., 2000), and/or receptor tyrosine phosphatase $\beta$ (Ratcliffe et al., 2000).

The effects of $\beta 2$ on $\mathrm{Na}_{\mathrm{v}} 1$ cell-surface expression have been well established in primary CNS neuronal cultures in vitro (Schmidt et al., 1985; Schmidt and Catterall, 1986) and in brains of $\beta 2^{-1-}$ mice in vivo (Chen et al., 2002). In primary CNS neuronal cultures, the expression of $\beta 2$ results in increased levels of $\mathrm{Na}_{\mathrm{v}} 1$ at the cell surface. The loss of $\beta 2$ results in a negative shift in the voltage dependence of $\mathrm{Na}_{\mathrm{v}} \mathrm{l}$ inactivation as well as significant decreases in $I_{\mathrm{Na}}$ density in acutely dissociated hippocampal neurons of $\beta 2^{-1-}$ mice (Chen et al., 2002). ${ }^{3} \mathrm{H}$-saxitoxin binding experiments showed that, although the total cellular level of channels is similar in $\beta 2^{+/+}$and $\beta 2^{-/-}$neurons, there is a $42 \%$ reduction in the level of plasma membrane channels in $\beta 2^{-1-}$ neurons, consistent with the observed decreases in $I_{\mathrm{Na}}$ density. The integral of the optic nerve compound action potential is reduced $30 \%$ in $\beta 2^{-I-}$ mice compared with control, and its dependence on stimulus strength is shifted to stronger stimuli, consistent with the reduction in channel cell-surface expression. These data clearly demonstrate that $\beta 2$ plays a critical role in regulating $\mathrm{Na}_{\mathrm{v}} 1$ density and functional expression in CNS neurons in vivo. 
The purpose of this study was to investigate the role of $\beta 2$ in sensory dorsal root ganglion (DRG) neurons. $\beta 2$ expression increases in sensory neurons after nerve injury, and $\beta 2^{-1-}$ mice develop less mechanical allodynia than their wild-type counterparts in the spared nerve injury (SNI) model (Pertin et al., 2005). We hypothesized that $\beta 2$ may modulate electrical excitability in DRG neurons in vivo. To test this hypothesis, we investigated both tetrodotoxin-sensitive (TTX-S) and tetrodotoxin-resistant (TTX-R) $I_{\mathrm{Na}}$ in DRG neurons isolated from $\beta 2^{+/+}$and $\beta 2^{-1-}$ mice. We report that TTX-S but not TTX-R $I_{\mathrm{Na}} \mathrm{s}$ are reduced $\sim 50 \%$ in "small-fast" DRG neurons isolated from $\beta 2^{-1-}$ mice compared with wild-type littermates. In addition, the activation and inactivation kinetics of TTX-S $I_{\mathrm{Na}}$ are slowed significantly. Behavioral studies show acute thermal hypersensitivity and reduced sensitivity to the inflammatory phase of the formalin test in $\beta 2$ null mice with no measurable differences in sensitivity to mechanical stimulation. We conclude that $\beta 2$ plays critical roles in electrical excitability in sensory neurons. Furthermore, $\beta 2$ may differentially affect subclasses of sensory neurons in the DRG.

\section{Materials and Methods}

Preparation of DRG neurons. The generation of $\beta 2^{-1-}$ (Scn2b null) mice was described previously (Chen et al., 2002). Animals used in the present study were bred from a congenic strain of $\beta 2^{+/-}$mice that had been backcrossed repeatedly to C57BL/6 for at least 10 generations. All animal experiments were performed in accordance with the guidelines of the University of Michigan Committee on Use and Care of Animals or the Committee on Animal Experimentation of the Canton of Vaud, Lausanne, Switzerland. DRG neurons were acutely dissociated from adult male ( $8-12$ weeks old) $\beta 2^{+/+}$or $\beta 2^{-/-}$littermate mice. Briefly, the mice were killed with $100 \% \mathrm{CO}_{2}$ inhalation for 1-2 min in a closed chamber. The vertebral column was then removed and cut longitudinally, and the DRGs on both sides from L4 and L5 spinal cord segments were removed. These ganglia were selected because $98 \%$ of sensory fibers in the sciatic nerve have cell bodies in the L4 and L5 DRGs (Swett et al., 1991). The DRGs were placed in minimal essential medium plus glutamine (Invitrogen, Carlsbad, CA) supplemented with $16.5 \mathrm{~mm} \mathrm{NaHCO}_{3}, 28.2 \mathrm{~mm}$ glucose, and distilled water or in DMEM/F-12 (Invitrogen) supplemented with $22 \mathrm{~mm}$ glucose, to give a final osmolarity of $320 \mathrm{mOsm} / \mathrm{l}$. The medium was filtered through a $0.2 \mu \mathrm{m}$ filter flask. The DRGs were minced two to three times before being incubated in medium with enzymes in a culture dish at $37^{\circ} \mathrm{C}$. The total incubation time was $50 \mathrm{~min}$ with enzymes added according to the following protocol: collagenase type II $(3 \mathrm{mg} / \mathrm{ml}$; Worthington, Lakewood, NJ) was present for the entire 50 min incubation; DNase type I ( $0.05 \mathrm{mg} / \mathrm{ml}$; Sigma, St. Louis, MO) and trypsin type I $(1 \mathrm{mg} / \mathrm{ml}$; Sigma) were added for the last 20 and $10 \mathrm{~min}$ of incubation, respectively. The dish was agitated every $10 \mathrm{~min}$ during the incubation. The enzymatic digestion was stopped by the addition of medium with BSA $(20 \mathrm{mg} / \mathrm{ml})$ before being replaced with fresh medium $(0.5 \mathrm{ml})$ lacking BSA. Cells remaining in tissue fragments were dispersed into the medium using sterile fire-polished and silicon-coated Pasteur pipettes (6-12 strokes up and down). The cellular suspension was plated on collagen-coated $35 \mathrm{~mm}$ culture dishes or glass coverslips and incubated at $37^{\circ} \mathrm{C}$ in a humidified atmosphere of $95 \%$ air plua $5 \% \mathrm{CO}_{2}$ for $1 \mathrm{~h}$. Finally, $2 \mathrm{ml}$ of medium supplemented with $10 \%$ fetal bovine serum were added. The cells were incubated for $2-10 \mathrm{~h}$ before recording, with the first $2 \mathrm{~h}$ used to allow cells to settle and adhere to the bottom of the culture dishes or coverslips. The remaining $8 \mathrm{~h}$ recording period was sufficiently short enough to minimize changes in electrical properties that may occur in long-term cultures.

Voltage-clamp recording. Voltage-clamp recordings were performed in the standard whole-cell configuration (Hamill et al., 1981), using an Axopatch 200B voltage-clamp amplifier (Molecular Devices, Union City, $\mathrm{CA})$. The cell capacitance $\left(C_{\mathrm{m}}\right)$ was calculated by integrating the area under capacitive transients as described previously (Meza et al., 1994) or read directly from the amplifier. Isolated $I_{\mathrm{Na}}$ were recorded from single small DRG neurons $\left(12 \mathrm{pF}<C_{\mathrm{m}}<42 \mathrm{pF}\right)$ at $21^{\circ} \mathrm{C}$ in the presence of a bath solution that contained the following (in $\mathrm{mm}$ ): $80 \mathrm{NaCl}$, 50 choline$\mathrm{Cl}, 30$ TEA-Cl, $2 \mathrm{CaCl}_{2}, 0.2 \mathrm{CdCl}_{2}, 10$ HEPES, and 5 glucose, $\mathrm{pH} 7.3$ with $\mathrm{NaOH}$. For some cells, the solution contained $40 \mathrm{~mm} \mathrm{NaCl}$ and $90 \mathrm{~mm}$ choline-Cl. Fire-polished patch pipettes were generated from borosilicate glass capillaries (Warner Instruments, Hamden, CT) using a Sutter P-87 puller (Sutter Instruments, Novato, CA) and were filled with an internal solution containing the following (in $\mathrm{mm}$ ): $70 \mathrm{CsCl}, 30 \mathrm{NaCl}, 30$ TEA-Cl, 10 EGTA, $1 \mathrm{CaCl}_{2}, 2 \mathrm{MgCl}_{2}, 2 \mathrm{Na}_{2} \mathrm{ATP}, 0.05$ GTP, 10 HEPES, and 5 glucose, $\mathrm{pH} 7.3$ with $\mathrm{CsOH}$. Glass coverslips to which the cells were attached were removed from the incubator and placed into a smallvolume recording chamber $(\sim 250 \mu \mathrm{l})$. Alternatively, if the cells were plated directly onto a $35 \mathrm{~mm}$ culture dish, $1 \mathrm{ml}$ of bath solution was used. All cells were subsequently examined within 10-60 min.

Currents were low-pass filtered at $5 \mathrm{kHz}$ with a four-pole Bessel filter and digitally sampled at 20 or $40 \mathrm{kHz}$. Capacitive transients were canceled with the amplifier circuitry, and linear leakage currents were digitally subtracted on-line with $\mathrm{P} / 4$ routines (Armstrong and Bezanilla, 1977). The use of the transient cancellation feature on the amplifier provided estimates for $C_{\mathrm{m}}$ and series resistance. The $C_{\mathrm{m}}$ estimated in this way was similar to that estimated by the integrating method (see above). Patch electrodes had resistances of $0.8-2.5 \mathrm{M} \Omega$, and the series resistance was typically in the range $1-5 \mathrm{M} \Omega$. When appropriate, this was reduced by $40-60 \%$ using the compensation circuit of the amplifier. The holding potential was always $-80 \mathrm{mV}$. Recordings were performed using pClamp 8 and 9 software (Molecular Devices).

To analyze the voltage dependence of channel activation, the sodium conductance $\left(G_{\mathrm{Na}}\right)$ was calculated. Peak current data for each cell were divided by the respective driving force $\left(V_{\mathrm{m}}-V_{\text {rev }}\right)$, plotted against $V_{\mathrm{m}}$, and fit to a Boltzmann equation of the following form:

$$
G_{\mathrm{Na}}=G_{\max } /\left(1+\exp \left(-\left(V_{\mathrm{m}}-V_{1 / 2}\right) / k\right)\right),
$$

where $G_{\max }$ is the maximum $G_{\mathrm{Na}}, V_{1 / 2}$ is the voltage at which $50 \%$ of the $\mathrm{Na}_{\mathrm{v}} 1$ are activated, and $k$ is the slope of the curve. Steady-state inactivation was measured by applying a double-pulse protocol, consisting of a $500 \mathrm{~ms}$ prepulse ranging from -120 to $20 \mathrm{mV}$ (in 5 and $10 \mathrm{mV}$ increments), followed by a test pulse to $0 \mathrm{mV}$. Each data set (a plot of peak $I_{\mathrm{Na}}$ during the $0 \mathrm{mV}$ test pulse vs prepulse voltage) was fit with the summation of two Boltzmann equations of the following form:

$I_{\mathrm{Na}}=F_{1} /\left[1+\exp \left(\left(V_{\mathrm{m}}-V_{1 / 2}^{1}\right) / k_{1}\right)\right]+F_{2} /\left[1+\exp \left(\left(V_{\mathrm{m}}-V_{1 / 2}^{2}\right) / k_{2}\right)\right]$,

where $F_{1}$ and $F_{2}$ are the fractions of the first and second components of inactivation, respectively. The most negative component (component 1) results from the TTX-S $I_{\mathrm{Na}}$ whereas the other results from TTX-R $I_{\mathrm{Na}}$. $V_{1 / 2}$ is the potential at which half of the $I_{\mathrm{Na}}$ was inactivated, and $k$ is the slope factor for each component. The sum of both fractions is the calculated maximum $I_{\mathrm{Na}}\left(F_{1}+F_{2}=I_{\text {max }}\right)$. Data points were then normalized with respect to $I_{\max }$ to obtain the inactivation curve. An alternate calculation method, yielding similar results, is included in the on-line supplemental material (available at www.jneurosci.org).

To examine the rate of channel recovery from inactivation, a protocol was designed comprising a $500 \mathrm{~ms}$ prepulse to $-120 \mathrm{mV}$, followed by a test pulse to $0 \mathrm{mV}$, and then returning to $-120 \mathrm{mV}$ for a variable time period $(0.25,0.5,1,2,4,6,8,10,20,30,40,50,75,100,200,300,400,500$, and $750 \mathrm{~ms}$ ) before application of a second test pulse to $0 \mathrm{mV}$. The $I_{\mathrm{Na}}$ amplitude from the second $0 \mathrm{mV}$ pulse was divided by the amplitude of the corresponding first test pulse to obtain the fraction of $I_{\mathrm{Na}}$ recovered after the recovery time. The data were fit with a double-exponential equation of the following form:

$$
I_{\mathrm{Nap} 2} / I_{\mathrm{Nap} 1}=f_{1} \times\left[1-\exp \left(-t / \tau_{1}\right)\right]+f_{2} \times\left[1-\exp \left(-t / \tau_{2}\right)\right],
$$

where $I_{\mathrm{Na} 2} / I_{\mathrm{Na} 1}$ is the fraction of current recovered; $f_{1}$ and $f_{2}$ are the fractions of the fast and slow recovery components, respectively; $t$ is recovery time; and $\tau_{1}$ and $\tau_{2}$ are the time constants for each recovery component.

Analysis of electrophysiological data. Data were analyzed using pClamp 8 and 9 (Molecular Devices) and SigmaPlot 7 (SPSS, Chicago, IL). The statistical significance of differences between mean values for $\beta 2^{+/+}$and $\beta 2^{-/-}$neurons was evaluated by Student's unpaired $t$ test, 
Table 1. Primer and probe sequences used for real-time RT-PCR

\begin{tabular}{|c|c|}
\hline Gene & Primer pairs $5^{\prime}-3^{\prime}$ \\
\hline \multirow[t]{2}{*}{$\mathrm{Na}_{\mathrm{v}} 1.1$} & Fw AACAAGCTTCATTCACATACAATAAG \\
\hline & Rev AGGAGGGCGGACAAGCTG \\
\hline \multirow[t]{2}{*}{$\mathrm{Na}_{\mathrm{v}} 1.2$} & Fw GGGAACGCCCATCAAAGAAG \\
\hline & Rev ACGCTATCGTAGGAAGGTGG \\
\hline \multirow[t]{2}{*}{$\mathrm{Na}_{\mathrm{v}} 1.3$} & Fw GGGTGTTGGGTGAGAGTGGAG \\
\hline & Rev AATGTAGTAGTGATGGGCTGATAAGAG \\
\hline \multirow[t]{2}{*}{$\mathrm{Na}_{\mathrm{v}} 1.6$} & Fw AGCAAAGACAAACTGGACGATACC \\
\hline & Rev CACTTGAACCTCTGGACACAACC \\
\hline \multirow[t]{2}{*}{$\mathrm{Na}_{\mathrm{v}} 1.7$} & Fw TCCTTTATTCATAATCCCAGCCTCAC \\
\hline & Rev GATCGGTTCCGTCTCTCTTTGC \\
\hline \multirow[t]{2}{*}{$\mathrm{Na}_{\mathrm{v}} 1.8$} & Fw ACCGACAATCAGAGCGAGGAG \\
\hline & Rev ACAGACTAGAAATGGACAGAATCACC \\
\hline \multirow[t]{2}{*}{$\mathrm{Na}_{\mathrm{v}} 1.9$} & Fw TGAGGCAACACTACTTCACCAATG \\
\hline & Rev AGCCAGAAACCAAGGTACTAATGATG \\
\hline \multirow[t]{2}{*}{$\beta 1$} & Fw GTGTATCTCCTGTAAGCGTCGTAG \\
\hline & Rev ATTCTCATAGGGTAGGATCTTGACAA \\
\hline \multirow[t]{2}{*}{$\beta 2$} & Fw GGCCACGGCAAGATTTACCT \\
\hline & Rev CACCAAGATGACCACAGCCA \\
\hline \multirow[t]{2}{*}{$\beta 3$} & Fw ACTGAAGAGGCGGGAGAAGAC \\
\hline & Rev GGTGAGGAAGACCAGGAGGATG \\
\hline \multirow[t]{2}{*}{$\beta 4$} & Fw CCCTTGGTGTAGAAACTAAGCAGAG \\
\hline & Rev CAGAAGCGAGTCAGTCAGATACG \\
\hline \multirow[t]{2}{*}{ GAPDH } & Fw TCCATGACAACTTTGGCATTG \\
\hline & Rev CAGTCTTCTGGGTGGCAGTGA \\
\hline
\end{tabular}

Fw, Forward; Rev, reverse.

with $p<0.050$ considered significant. Results are presented as means \pm SEM.

Real-time reverse transcription-PCR. Unilateral L3-L5 DRGs from $\beta 2^{+/+}$and $\beta 2^{-1-}$ mice were rapidly dissected and collected in RNAlater solution (Qiagen AG, Basel, Switzerland). Each individual sample consisted of a pool of six DRGs dissected from two animals. Total RNA was isolated from each individual sample using the RNeasy Mini kit (Qiagen AG) with a DNase step (RNase free DNase set; Qiagen AG) on the column. After RNA quality and quantity were assessed by electrophoresis and spectrophotometry, $1.5 \mu \mathrm{g}$ of RNA for each sample was reverse transcribed using Omniscript reverse transcriptase following the manufacturer's instructions (Qiagen AG). Beacon Designer 3.0 software (Primer Biosoft International, Palo Alto, CA) was used to design primer and probe sequences (Table 1) according to SYBR green specifications (Vandesompele et al., 2002). Glyceraldehyde-3-phosphate dehydrogenase (GAPDH) was chosen as an endogenous control to normalize expression levels of the different $\mathrm{Na}_{\mathrm{v}} 1 \alpha$ and $\beta$ subunits. Real-time PCRs were performed in a $20 \mu \mathrm{l}$ total volume containing $50 \mathrm{ng}$ of cDNA, 300 nM of each primer, $10 \mu \mathrm{l}$ of $2 \times$ iQ SYBR green mix containing nucleotides, iTaq DNA polymerase, SYBR green, and fluorescein (Bio-Rad, Reinach, Switzerland) using the MyiQ Single Color Real-Time PCR Detection System (Bio-Rad). The amplification protocol was as follows: 3 min at $95^{\circ} \mathrm{C}, 45 \mathrm{cycles}$ of $10 \mathrm{~s}$ at $95^{\circ} \mathrm{C}$ for denaturation, and $45 \mathrm{~s}$ at $60^{\circ} \mathrm{C}$ for annealing and extension; specificity was assessed using a DNA melting curve by measuring fluorescence during gradual temperature increments $\left(0.5^{\circ} \mathrm{C}\right)$ from 55 to $95^{\circ} \mathrm{C}$.

To determine the profile of expression of different $\mathrm{Na}_{\mathrm{v}} 1$ subunits $\left(\mathrm{Na}_{\mathrm{v}} 1.1, \mathrm{Na}_{\mathrm{v}} 1.2, \mathrm{Na}_{\mathrm{v}} 1.3, \mathrm{Na}_{\mathrm{v}} 1.6, \mathrm{Na}_{\mathrm{v}} 1.7, \mathrm{Na}_{\mathrm{v}} 1.8\right.$, and $\mathrm{Na}_{\mathrm{v}} 1.9$ and $\beta 1, \beta 2$, $\beta 3$, and $\beta 4)$ in $\beta 2^{-1-}$ and $\beta 2^{+/+}$mice, a pool of three samples of each cDNA was used. PCR was performed in triplicate.

The level of expression of $\mathrm{Na}_{\mathrm{v}} 1 \alpha$ and $\beta$ subunits detected in $\beta 2^{-1-}$ and $\beta 2^{+/+}$mice was determined using four individual samples of total RNA from each genotype; each amplification was performed in triplicate for each target mRNA. The efficiency of amplification was determined by serial dilution of starting DNA, and standard curves were constructed from the respective mean critical threshold $\left(C_{\mathrm{T}}\right)$ value for GAPDH and $\mathrm{Na}_{\mathrm{v}} 1$ transcripts. The relative expression of each target gene was calculated based on real-time PCR efficiencies and the threshold value of the unknown sample versus the standard sample (Pfaffl, 2001).

Western blot analysis of DRG membrane preparations. DRGs were re- moved and stored in ice-cold dissection medium. After a brief centrifugation at $4^{\circ} \mathrm{C}$, the supernatant was discarded and the DRGs were rinsed two times in Tris-EGTA buffer (50 mm Tris, $\mathrm{pH} 8.0$ with $\mathrm{NaOH}$, and 10 mM EGTA) containing Complete protease inhibitors (Roche, Indianapolis, IN) at twice the recommended concentration. The DRGs were homogenized and centrifuged at $3000 \times g$ for $5 \mathrm{~min}$ at $4^{\circ} \mathrm{C}$ to remove nuclei. The supernatant was ultra-centrifuged at $4^{\circ} \mathrm{C}$ for $10 \mathrm{~min}$ at $195,000 \times \mathrm{g}$, and the pellets resuspended in $60 \mu \mathrm{l}$ of Tris-EGTA buffer containing Complete protease inhibitors. One microliter of the suspension was used for protein assay. Equal amounts of protein $(100 \mu \mathrm{g})$ were loaded on $4-15 \%$ polyacrylamide gradient gels and separated by SDS-PAGE. Proteins were then transferred to nitrocellulose as described previously (McEwen et al., 2004). Blots were probed with specific $\mathrm{Na}_{\mathrm{v}} 1 \alpha$ subunit antibodies. Anti-Na 1.1 (Chemicon, Temecula, CA) was used at a 1:500 dilution, anti- $\mathrm{Na}_{\mathrm{v}} 1.7$ (Chemicon) was used at a 1:500 dilution, and anti$\mathrm{Na}_{\mathrm{v}} 1.6$ (Neuromab) was used at a 1:100 dilution. All blots were subsequently probed with anti- $\alpha$-tubulin diluted 1:5000 (Cedarlane Laboratories, Hornby, Ontario, Canada). The immune signal from this housekeeping protein was used to control for loading differences. Densitometric measurement of the immunoreactive $\mathrm{Na}_{\mathrm{v}} 1 \alpha$ bands was performed using Scion (Frederick, MD) Image. Each $\mathrm{Na}_{\mathrm{v}} 1$ band was first normalized to the corresponding $\alpha$-tubulin band for each lane on the gel. $\mathrm{Na}_{\mathrm{v}} 1$ expression levels in the $\beta 2^{-/-}$lanes were then calculated as a percentage of the corresponding wild-type levels, using the $\alpha$-tubulin normalized $\beta 2^{+/+} \mathrm{Na}_{\mathrm{v}} 1$ levels as $100 \%$.

Behavioral tests. Eight-week-old male $\beta 2^{-1-}$ or $\beta 2^{+/+}$mice were habituated to the environment, the tester, and the apparatus for at least 2 weeks before testing. All behavioral testing was performed by an observer blinded to the mouse genotype.

The hot-plate assay was conducted by placing the animals $(n=9$ in each group) on the hot-plate surface set at varying temperatures $(49,52$, and $55^{\circ} \mathrm{C}$ ) (Cao et al., 1998). The latency of response was determined by a clear hindpaw lick. The cutoff was adjusted for each temperature to avoid tissue damage: $60 \mathrm{~s}$ for $49^{\circ} \mathrm{C}, 30 \mathrm{~s}$ for $52^{\circ} \mathrm{C}$, and $20 \mathrm{~s}$ for $55^{\circ} \mathrm{C}$.

The tail-flick assay was conducted using a tail-flick analgesia meter (Columbus Instrument, Columbus, $\mathrm{OH}$ ), and the mice were gently restrained in a conic plastic cloth. The latency of response was recorded manually at two different light-beam intensities ( 4 and $7 ; n=4$ in each group) with a cutoff at $20 \mathrm{~s}$ (Wilson and Mogil, 2001).

Mechanical sensitivity assessment was performed by applying an ascending series of non-noxious Von Frey monofilaments (Stoelting, Wood Dale, IL) to the plantar surface of each hindpaw $(n=9$ in each group). For this purpose, mice were placed on an elevated platform with a delicate wire netting floor. The withdrawal threshold (in grams) was defined as the lowest force that evoked a brisk withdrawal response to at least 2 of 10 stimuli (Suter et al., 2003).

For the formalin test, $10 \mu \mathrm{l}$ of $5 \%$ formalin (formaldehyde; Sigma, St. Louis, MO) was injected subcutaneously in the left hindpaw $(n=6$ in each group). The time the animal spent shaking/flinching and licking the injected paw was recorded for each 5 min interval, from the injection time up to $80 \mathrm{~min}$ (Wei et al., 2001).

Analysis of behavioral data. Data are represented as mean \pm SEM. Differences between groups were compared using one- or two-way ANOVA for unpaired variables, followed by post hoc Bonferroni's correction when appropriate. Von Frey series present logarithmic differences between hairs, and logarithmic-transformed values were used for the analysis, enabling ANOVA tests (Suter et al., 2003). Statistical analyses were performed using JMP statistical software (version 5.01; SAS Institute, Cary, NC). A $p$ value $\leq 0.05$ was considered statistically significant.

\section{Results}

\section{Identification and definition of neuronal size}

Using criteria described in previous studies (Abdulla and Smith, 2001, 2002), DRG neurons were first assigned to "small," "medium," or "large" groups on the basis of their $C_{\mathrm{m}}:<42,42-72$, and $>72 \mathrm{pF}$, respectively $\left(\beta 2^{+/+}\right.$cells, $n=89 ; \beta 2^{-1-}$ cells, $n=$ $85)$. There were no differences in the proportions of small, me- 
A
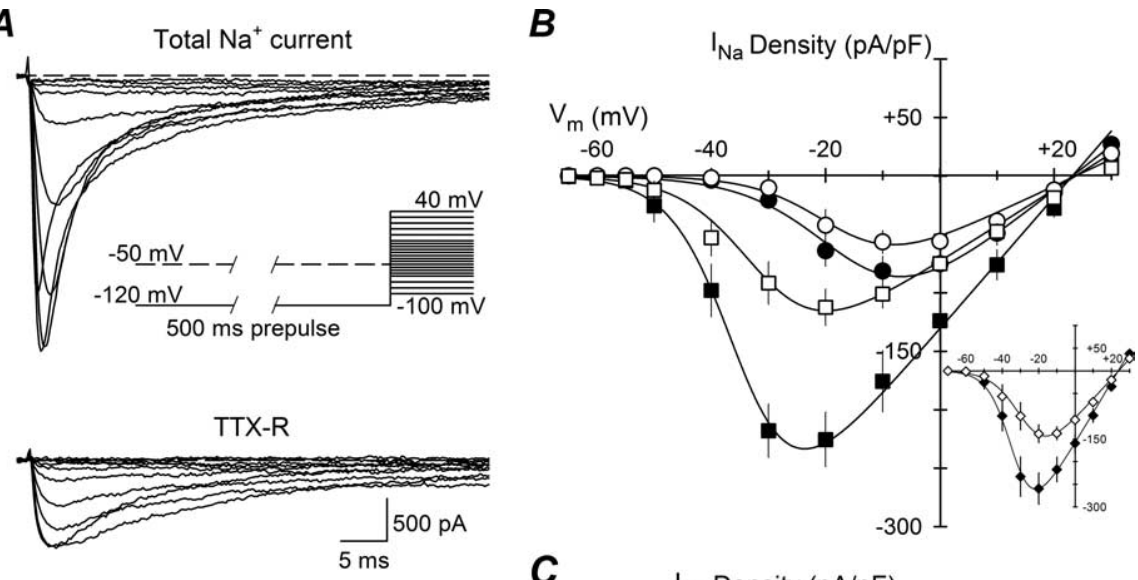

C

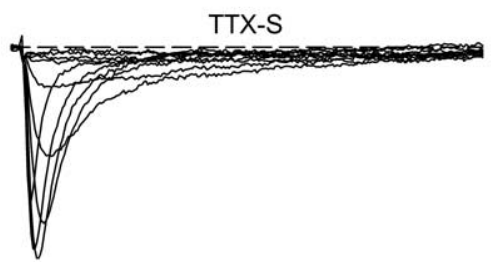

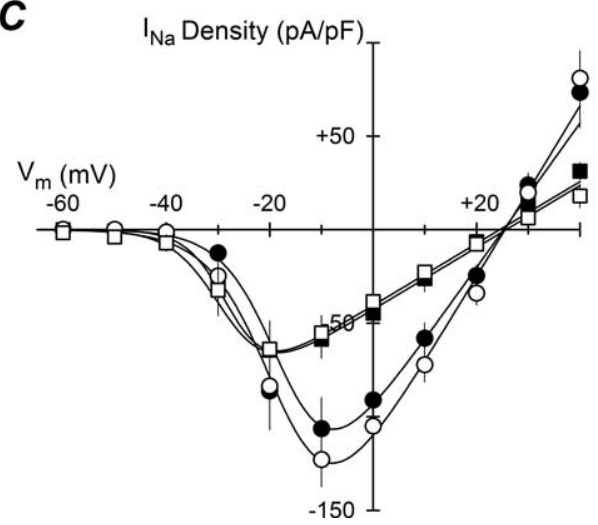

Figure 1. Current-voltage relationships. A, Protocol for separation of TTX-R and TTX-S $I_{\mathrm{Na}}$. A $500 \mathrm{~ms}$ prepulse to -120 or -50 $\mathrm{mV}$ was applied before a $50 \mathrm{~ms}$ test pulse from -100 to $40 \mathrm{mV}$ with steps of 5 or $10 \mathrm{mV}$ (inset). Currents evoked from one $\beta 2^{-1-}$ small-fast DRG neuron by test pulses from -50 to $0 \mathrm{mV}$ are shown. Both TTX-S and TTX-R Na $_{\mathrm{Na}}$ were apparent after the $-120 \mathrm{mV}$ prepulse (top traces); only TTX-R I ${ }_{\mathrm{Na}}$ were obtained after the $-50 \mathrm{mV}$ prepulse (middle traces), and the TTX-S component was obtained (bottom traces) by digitally subtracting the TTX-R $I_{\mathrm{Na}}$ from the total $I_{\mathrm{Na}} B$, Average peak $I_{\mathrm{Na}}$ density-voltage relationships for TTX-R $I_{\mathrm{Na}}$ (circles) and TTX-S $I_{\mathrm{Na}}$ (squares) of small-fast DRG neurons (means \pm SEM), $\beta 2^{+/+}$(closed symbols; $n=15$ ), or $\beta 2^{-I-}$ (open symbols; $n=14$ ). Smooth lines are $I-V$ curves generated using the Boltzmann fit parameters of the respective activation curves. Inset, $I-V$ curves of total $I_{\mathrm{Na}}$ from the same cells as in $A, \beta 2^{+/+}$(closed symbols) and $\beta 2^{-I-}$ (open symbols). C, Similar to $\boldsymbol{B}$, but for small-slow neurons, $\beta 2^{+/+}$(closed symbols; $n=14$ ), or $\beta 2^{-/-}$(open symbols; $n=11$ ).

dium, and large cells between the two strains (data not shown). We focused this study on small neurons, with a mean $C_{\mathrm{m}}$ of $24.9 \pm 1.7 \mathrm{pF}(n=35)$ for $\beta 2^{+/+}$neurons and $23.9 \pm 1.4 \mathrm{pF}(n=$ 32) for $\beta 2^{-/-}$neurons. Assuming a specific $C_{\mathrm{m}}$ of $1 \mu \mathrm{F} / \mathrm{cm}^{2}$ (Hille, 2001), and that the cells have a spherical shape without invaginations, cell-surface area and diameter can be estimated. Thus, the mean $C_{\mathrm{m}}$ corresponds to cell diameters of 28.1 and 27.6 $\mu \mathrm{m}$, respectively, for $\beta 2^{+/+}$and $\beta 2^{-/-}$neurons. Neurons with diameters $<30 \mu \mathrm{m}$ were considered nociceptive neurons, or type C cells (Study and Kral, 1996; Flake et al., 2004).

Total $I_{\mathrm{Na}}$, the sum of TTX-S and TTX-R $I_{\mathrm{Na}}$ (Roy and Narahashi, 1992; Rush et al., 1998; Abdulla and Smith, 2002; Dib-Hajj et al., 2002), was recorded using a series of depolarizing voltage commands from a holding potential of $-80 \mathrm{mV}$. To explore the voltage dependence of $I_{\mathrm{Na}}$ in DRG neurons of $\beta 2^{+/+}$and $\beta 2^{-/-}$ mice, we took advantage of the previously described activation and inactivation properties of peripheral nerve $\mathrm{Na}_{\mathrm{v}} 1$ (Cummins and Waxman, 1997; Akopian et al., 1996, 1999). Thus, a currentvoltage $(I-V)$ protocol with a $500 \mathrm{~ms}$ prepulse to -120 or -50 $\mathrm{mV}$, followed by a test pulse from -100 to $+40 \mathrm{mV}$ was applied, with steps of 5 and $10 \mathrm{mV}$, waiting $10 \mathrm{~s}$ between each step (Fig. $1 A$, inset). When the $I-V$ protocol with a prepulse to $-120 \mathrm{mV}$ was applied, the total $I_{\mathrm{Na}}$ was obtained (Fig. $1 \mathrm{~A}$, top traces). A second $I-V$ protocol was subsequently applied to the same cell, but with a prepulse to $-50 \mathrm{mV}$, to inactivate TTX-S $I_{\mathrm{Na}}$ and thus record only the TTX-R component (Fig. 1A, middle traces). Finally, the TTX-S component was obtained by digitally subtracting the data obtained with the second protocol from the first (Fig. 1A, bottom traces). Similar results were obtained using $300 \mathrm{~nm}$ TTX on some cells (data not shown). This protocol has the advantage of obtaining separate $I-V$ relationships for both TTX-S and TTX-R $I_{\mathrm{Na}}$ in the absence of TTX, thus saving time and reducing cell deterioration. The two $I-V$ curves allow us to classify the small neurons into two subgroups: small-fast and "small-slow" DRG neurons. When the maximum amplitude of TTX-S $I_{\mathrm{Na}}$ was $>70 \%$ of the total $I_{\mathrm{Na}}$, the cells were placed in the small-fast subgroup (Abdulla and Smith, 2002). These cells made up $49 \%$ (17 of 35 ) of the $\beta 2^{+/+}$ small cell population and 53\% (17 of 32) of the $\beta 2^{-1-}$ small neurons. Cells placed in the second subgroup had TTX-R $I_{\mathrm{Na}}>70 \%$ of the total $I_{\mathrm{Na}}$. These cells made up $46 \%$ (16 of 35 ) of the $\beta 2^{+/+}$and $41 \%$ (13 of 32) of the $\beta 2^{-1-}$ small cells. $I_{\mathrm{Na}}$ in the $6 \%$ of cells remaining from the total cell population, two cells of each genotype, did not clearly fall into either category. Thus, these cells were not included in our analysis.

\section{The absence of $\beta 2$ results in reduced TTX-S $I_{\mathrm{Na}}$}

Plots of peak $I_{\mathrm{Na}}$ density versus command voltage for small-fast and small-slow DRG neurons are shown in Figure $1, B$ and $C$, respectively. For both $\beta 2^{+/+}(n=15)$ and $\beta 2^{-1-}(n=14)$ small-fast DRG neurons, the main $I_{\mathrm{Na}}$ was TTX-S, as expected by definition. The activation threshold for this $I_{\mathrm{Na}}$ was between -55 and $-50 \mathrm{mV}$, and the maximum inward $I_{\mathrm{Na}}$ fell between -30 and $-20 \mathrm{mV}$. For both $\beta 2^{+/+}(n=14)$ and $\beta 2^{-1-}(n=11)$ small-slow neurons, the main $I_{\mathrm{Na}}$ was TTX resistant, detectable between -40 and -30 $\mathrm{mV}$ with maximal inward $I_{\mathrm{Na}}$ at approximately $-10 \mathrm{mV}$. All currents measured displayed a reversal potential $\left(V_{\text {rev }}\right)$ of $\sim 25$ $\mathrm{mV}$, corresponding to the calculated equilibrium potential for sodium ions under these recording conditions $\left(E_{\mathrm{Na}}=25 \mathrm{mV}\right)$. The $I-V$ curves for small-fast neurons from $\beta 2^{-I-}$ mice show a significant reduction in TTX-S $I_{\mathrm{Na}}$ density compared with those neurons isolated from $\beta 2^{+/+}$mice (Fig. $1 B$ ). This reduction can also be clearly observed directly in the total $I_{\mathrm{Na}}$ (Fig. $1 \mathrm{~B}$, inset).

To better compare the voltage dependence of channel activation, the sodium conductance $\left(G_{\mathrm{Na}}\right)$ was calculated as described in Materials and Methods. For $\beta 2^{+/+}$and $\beta 2^{-1-}$ small-slow DRGs neurons (Fig. 2C,D), $V_{1 / 2}$ and $k$ were similar for both TTX-R and TTX-S $I_{\mathrm{Na}}$; only $G_{\max }$ for TTX-S $I_{\mathrm{Na}}$ showed a reduction of $\sim 29 \%$ in $\beta 2^{-/-}$neurons compared with $\beta 2^{+/+}$neurons, however this reduction was not significant $(p=0.665)$. For small-fast cells, the mean value of $V_{1 / 2}$ and $k$ were also similar for TTX-R and TTX-S $I_{\mathrm{Na}}$ between groups (Fig. $2 B$ ). The $G_{\max }$ for TTX-R $I_{\mathrm{Na}}$ was $\sim 30 \%$ smaller in $\beta 2^{-1-}$ cells compared with $\beta 2^{+/+}$(Fig. $2 A$, dashed lines), but, again, this difference was not 
A

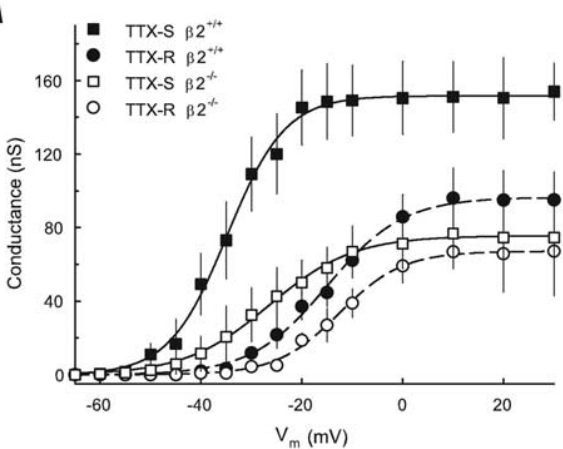

$C$

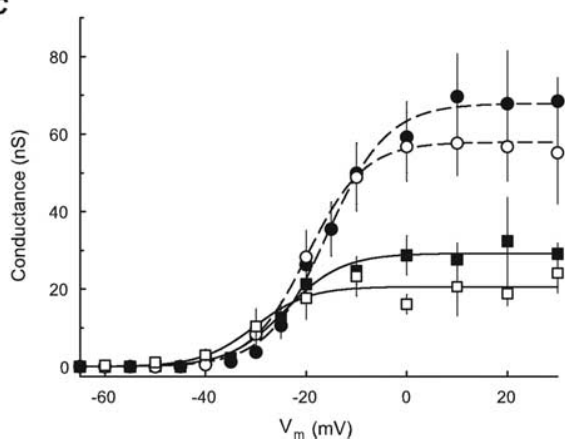

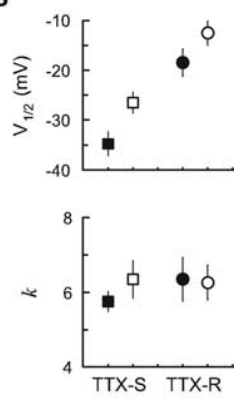

D

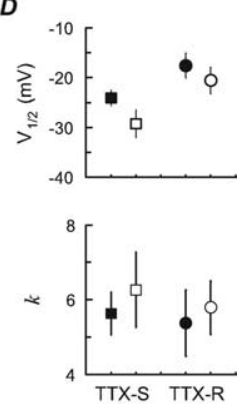

A

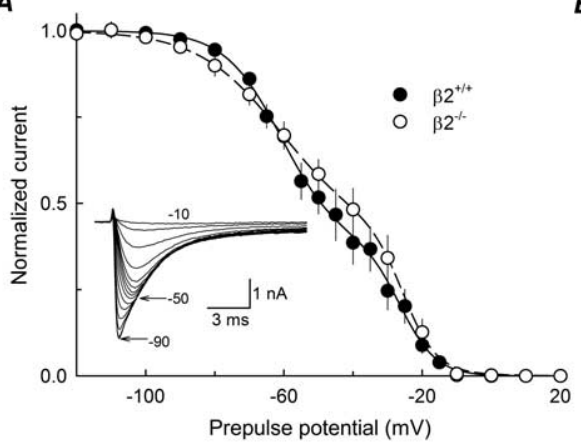

C

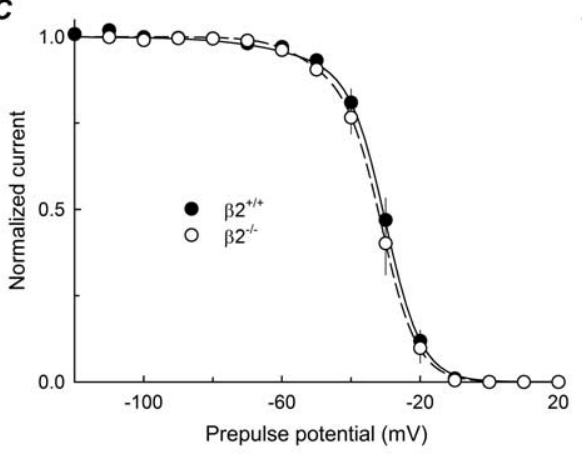

B

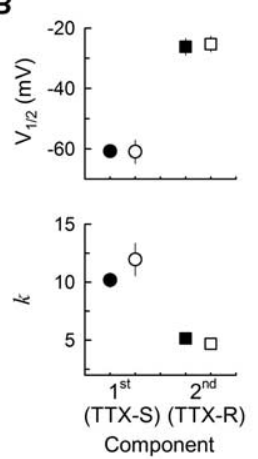

D
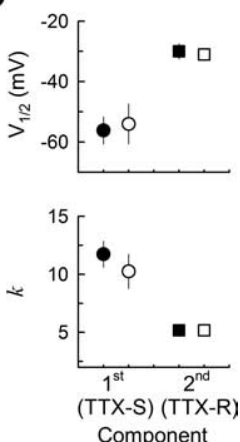

Figure 2. Voltage dependence of activation. $\boldsymbol{A}$, Activation curve of peak sodium conductance: TTX-R (circles) and TTX-S (squares) obtained from the same small-fast cells as in Figure $1 B, \beta 2^{+/+}$(closed symbols), and $\beta 2^{-/-}$(open symbols). Smooth lines are fits to a Boltzmann function for TTX-R (dashed lines) and TTX-S (solid lines) currents, respectively. B, Midpoint potential $\left(V_{1 / 2}\right)$ and slope factor $(k)$ of fitted activation curves of small-fast cells. C, D, Same small-slow cells as in Figure $1 \boldsymbol{C}$ with symbols as in $\boldsymbol{A}$ and $\boldsymbol{B}$. Error bars indicate SEM.

significant $\left(p=0.083\right.$ ). In contrast, the $G_{\max }$ for TTX-S $I_{\mathrm{Na}}$ measured in $\beta 2^{-1-}$ neurons was $\sim 51 \%$ smaller than that observed in $\beta 2^{+/+}$cells (Fig. $2 A$, solid lines), and this reduction was statistically significant $(p=0.001)$. These results suggest that $\beta 2$ subunits regulate cell-surface levels of TTX-S but not TTX- $\mathrm{R} \mathrm{Na}_{\mathrm{v}} 1$ in DRG neurons. Alternatively, it is possible that $\beta 2$ alters TTX-S $\mathrm{Na}_{\mathrm{v}} 1$ single-channel conductance; however, based on our previous results (Isom et al., 1995b; Chen et al., 2002), we propose that the former is the most likely mechanism of $\beta 2$ action.

$\beta 2$ does not affect the voltage dependence of $I_{\mathrm{Na}}$ inactivation Steady-state inactivation was measured as described in Materials and Methods. An example of the $I_{\mathrm{Na}}$ obtained from a typical small-fast $\beta 2^{+/+}$neuron in response to a test pulse to $0 \mathrm{mV}$ is shown in the inset to Figure $3 A$. In this example, as in practically all small-fast DRG neurons tested, the fast $I_{\mathrm{Na}}$ (TTX-S) is inactivated at more negative voltages than the slow $I_{\mathrm{Na}}$ (TTX-R). The mean of the individual curves are shown in Figure $3 A$ for smallfast neurons and in Figure $3 C$ for small-slow neurons. The corresponding $V_{1 / 2}$ and $k$ are compared in Figure 3, $B$ and $D$. The voltage dependence of TTX-S and TTX-R $I_{\mathrm{Na}}$ inactivation in small $\beta 2^{-l-}$ neurons was nearly identical to that of TTX-S and TTX-R $I_{\mathrm{Na}}$ of small $\beta 2^{+/+}$neurons (Fig. 3), therefore the $\beta 2$ subunit does not regulate the $I_{\mathrm{Na}}$ voltage dependence in small DRG neurons.

According to our classification of cells into small-fast and small-slow based on the proportion of TTX-S $I_{\mathrm{Na}}$ to that of TTX-R $I_{\mathrm{Na}}$, the average values of $F_{1}$ and $F_{2}$ (the proportion of TTX-S and TTX-R $I_{\mathrm{Na}}$ ) are close to 0.7 and 0.3 , respectively, for both $\beta 2^{+/+}$and $\beta 2^{-/-}$small-fast cells. For small-slow cells, $F_{1}$

Figure 3. Voltage dependence of inactivation. $A$, Peak $/$ a at $0 \mathrm{mV}$, normalized to its maximal value (inset), as a function of voltage during a $500 \mathrm{~ms}$ prepulse. $I_{\mathrm{Na}}$ were measured from $\beta 2^{+/+}\left(n=13\right.$; closed circles) and $\beta 2^{-/-}(n=10$; open circles) small-fast DRG neurons. Each data set was fit with a double Boltzmann function (lines). The inset is an example of $I_{\mathrm{Na}}$ at $0 \mathrm{mV}$, from one small-fast $\beta 2^{+/+}$cell, after $500 \mathrm{~ms}$ prepulses from -90 to $-10 \mathrm{mV}$. $\boldsymbol{B}$, Parameters of fitted inactivation curves shown in $A$; circles represent the first component (TTX$S)$, and squares represent the second component (TTX-R). $C, D$, Inactivation curves and parameters, respectively, for small-slow $\beta 2^{+/+}(n=12)$ and $\beta 2^{-/-}(n=8)$ neurons; symbols are as in $\boldsymbol{A}$ and $\boldsymbol{B}$. Error bars indicate SEM.

and $F_{2}$ are $\sim 0.1$ and 0.9 , respectively. Thus, the main $I_{\mathrm{Na}}$ for small-fast cells is TTX-S, whereas for small-slow cells it is TTX-R.

\section{Effects of $\beta 2$ on $I_{\mathrm{Na}}$ kinetics}

The rate of channel recovery from inactivation was measured as described in Materials and Methods. A typical set of $I_{\mathrm{Na}}$ traces obtained using this protocol is shown in the inset of Figure 4. In agreement with previous reports, the recovery from inactivation curve shows two components: the TTX-R $I_{\mathrm{Na}}$ shows fast recovery, and the TTX-S $I_{\mathrm{Na}}$ shows slow recovery (Cummins and Waxman, 1997; Rush et al., 1998). Time constants for $\beta 2^{+/+}$were $\tau_{1}=$ $1.3 \pm 0.2 \mathrm{~ms}$ and $\tau_{2}=95.3 \pm 17.8 \mathrm{~ms}(n=6)$, and time constants for $\beta 2^{-1-}$ were $\tau_{1}=1.5 \pm 0.5 \mathrm{~ms}$ and $\tau_{2}=83.3 \pm 29.4 \mathrm{~ms}(n=$ 6 ); the fraction of TTX-S $I_{\mathrm{Na}}$ was $0.88 \pm 0.03$ and $0.80 \pm 0.12$ for $\beta 2^{+/+}$and $\beta 2^{-/-}$, respectively. There were no significant differences between groups.

Superimposition of $I_{\mathrm{Na}}$ obtained from small-fast $\beta 2^{+/+}$and $\beta 2^{-1-}$ neurons suggested different rates of channel activation and inactivation (Fig. 5A). To evaluate the activation kinetics, two points on each time course were measured: the time to achieve $50 \%$ of the maximum current after onset of the test pulse to $0 \mathrm{mV}\left(T_{1 / 2}\right.$ peak $)$, and the time to achieve the peak $I_{\mathrm{Na}}$ with the same test pulse $\left(T_{\text {peak }}\right)$. Comparing both groups of small-fast neurons, these times were significantly different (Fig. $5 B$ ) with $T_{1 / 2 \text { peak }}$ and $T_{\text {peak }}$ for $\beta 2^{-/-}(n=12), 60$ and $69 \%$ longer than $\beta 2^{+/+}(n=16)$ neurons, respectively. To evaluate the inactivation kinetics for the same $I_{\mathrm{Na}}$, the decaying phase of the $I_{\mathrm{Na}}$ was fit 


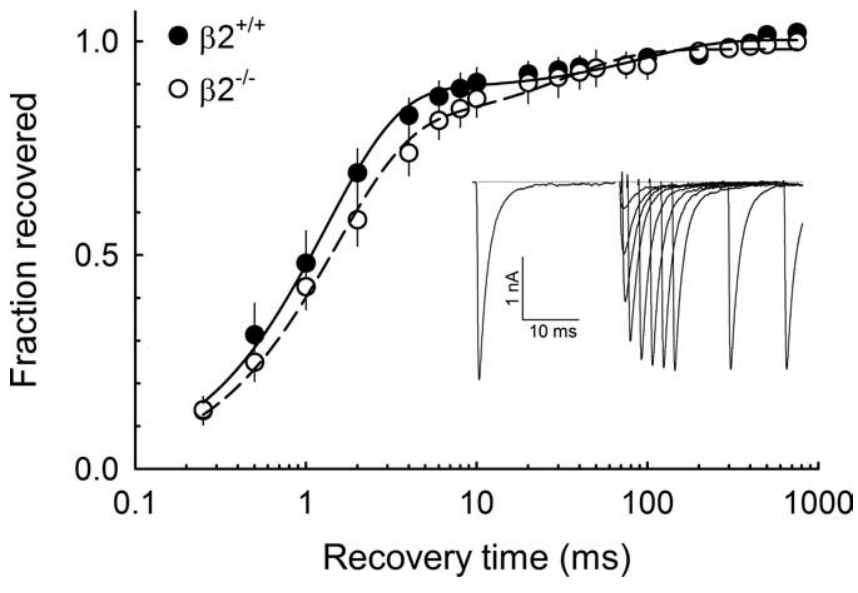

Figure 4. Recovery from inactivation. The average time course of recovery from inactivation for total $I_{\mathrm{Na}}$ from small-fast neurons $\beta 2^{+/+}$(closed symbols; $n=6$ ) and $\beta 2^{-/-}$(open symbols; $n=5$ ) is shown. The data were fit with a double exponential (lines) with the following results: for $\beta 2^{+/+}, \tau_{1}=1.3 \pm 0.2 \mathrm{~ms}$ and $\tau_{2}=95.3 \pm 17.8 \mathrm{~ms}$; for $\beta 2^{-/-}, \tau_{1}=1.5 \pm$ $0.5 \mathrm{~ms}$ and $\tau_{2}=83.3 \pm 29.4 \mathrm{~ms}$. Inset, A representative record from one $\beta 2^{+/+}$cell shows $I_{\mathrm{Na}}$ obtained from recovery intervals of $0.25-30 \mathrm{~ms}$ to $-120 \mathrm{mV}$. Error bars indicate SEM.

using a double-exponential function, obtaining two inactivation time constants $\left(\tau_{\text {fast }}\right.$ and $\left.\tau_{\text {slow }}\right)$. Only $\tau_{\text {fast }}$ was affected by the loss of $\beta 2$ expression (Fig. $5 C$ ): $\tau_{\text {fast }}=1.25 \pm 0.17 \mathrm{~ms}$ for $\beta 2^{+/+}$ neurons compared with $2.13 \pm 0.23 \mathrm{~ms}$ for $\beta 2^{-1-}$ neurons, an increase of $\sim 70 \%$. In contrast, $\tau_{\text {slow }}$ was the same for both groups (Fig. 5C). We performed similar analyses for small-slow $\beta 2^{+1+}$ $(n=11)$ and $\beta 2^{-1-}(n=9)$ neurons. Neither activation nor inactivation kinetics were statistically different (data not shown).

\section{$\mathrm{Na}_{\mathrm{v}} 1 \mathrm{mRNA}$ levels are regulated by $\boldsymbol{\beta} 2$}

To begin to investigate the molecular basis for the observed reduction in TTX-S $I_{\mathrm{Na}}$ in $\beta 2^{-/-}$neurons, we measured $\mathrm{Na}_{\mathrm{v}} 1 \alpha$ and $\beta$ subunit mRNA levels in DRGs from both wild-type and null mice. The profile of expression and relative abundance of $\mathrm{Na}_{\mathrm{v}} 1$ subunit transcripts $\left(\mathrm{Na}_{\mathrm{v}} 1.1, \mathrm{Na}_{\mathrm{v}} 1.2, \mathrm{Na}_{\mathrm{v}} 1.3, \mathrm{Na}_{\mathrm{v}} 1.6, \mathrm{Na}_{\mathrm{v}} 1.7\right.$, $\mathrm{Na}_{\mathrm{v}} 1.8$, and $\mathrm{Na}_{\mathrm{v}} 1.9$ and $\beta 1, \beta 2, \beta 3$, and $\beta 4$ ) (Table 1 ) were evaluated independently in $\beta 2^{+/+}$and $\beta 2^{-/-}$mice by real-time reverse transcription (RT)-PCR. $\mathrm{Na}_{\mathrm{v}} 1$ subunit mRNA levels were normalized to the highest $\mathrm{Na}_{\mathrm{v}} 1$ subunit transcript expressed in $\beta 2^{+/+}$DRGs: $\mathrm{Na}_{\mathrm{v}} 1.7$ for $\alpha$ subunits and $\beta 1$ for $\beta$ subunits (Fig. $6)$. In both genotypes, the order of the $\mathrm{Na}_{\mathrm{v}} 1$ subunit transcript expression levels was the same, with the exception of $\beta 2$ in the null mice: $\mathrm{Na}_{\mathrm{v}} 1.7>\mathrm{Na}_{\mathrm{v}} 1.8>\mathrm{Na}_{\mathrm{v}} 1.9>\mathrm{Na}_{\mathrm{v}} 1.6>\mathrm{Na}_{\mathrm{v}} 1.1>$ $\mathrm{Na}_{\mathrm{v}} 1.3>\mathrm{Na}_{\mathrm{v}} 1.2$ and $\beta 1>\beta 4>\beta 3>\beta 2$. In $\beta 2^{+/+}$DRGs, the $\mathrm{Na}_{\mathrm{v}} 1.7$ transcript was the most abundant. It was twice as abundant as $\mathrm{Na}_{\mathrm{v}} 1.6, \sim 7$ times more abundant than $\mathrm{Na}_{\mathrm{v}} 1.3$ or $\mathrm{Na}_{\mathrm{v}} 1.1$, and $\sim 25$ times more abundant than $\mathrm{Na}_{\mathrm{v}} 1.2$, all TTX-S channels. In addition, $\mathrm{Na}_{\mathrm{v}} 1.7$ was more abundant than transcripts for the TTX-R channels $\mathrm{Na}_{\mathrm{v}} 1.8$ and $\mathrm{Na}_{\mathrm{v}} 1.9$ (Fig. $6 A$ ). For mRNA of $\beta$ subunits, $\beta 1$ was $6-10$ times more abundant than the other $\beta$ subunits (Fig. $6 B$ ). Interestingly, $\beta 2$ appeared to be the lowest expressed $\beta$ subunit mRNA; however, as shown above, it plays a major functional role in DRG neurons.

In $\beta 2^{-1-}$ DRGs, the profile of $\alpha$ and $\beta$ subunit expression did not change, with the exception of $\beta 2$. However, the abundance of some subunit transcripts did change, notably $\mathrm{Na}_{\mathrm{v}} 1.7(p=0.043)$ (Fig. 6). Experiments were then performed to determine the ratios of specific subunit mRNA expression levels in null versus wild-type neurons. $\beta 2^{+/+}$and $\beta 2^{-1-}$ DRGs were assessed by real-time RT-PCR and normalized to GAPDH. The ratios of
$\mathrm{Na}_{\mathrm{v}} 1 \alpha$ and $\beta$ subunit transcript levels in $\beta 2^{-/-} / \beta 2^{+/+}$DRGs are shown in Figure 7. The expression levels of three TTX-S $\mathrm{Na}_{\mathrm{v}} 1$ transcripts, $\mathrm{Na}_{\mathrm{v}} 1.3, \mathrm{Na}_{\mathrm{v}} 1.6$ and $\mathrm{Na}_{\mathrm{v}} 1.7$, were significantly reduced $(p<0.05) 20-25 \%$ by the $\beta 2$ null mutation (Fig. $7 A$ ); similar reductions were found for $\beta 3$ and $\beta 4$ mRNAs (Fig. $7 B$ ), whereas no changes were observed for the other subunits.

\section{TTX-S Na 1 protein is regulated by $\boldsymbol{\beta} 2$}

Western blot analyses of membrane preparations of DRG neurons for the TTX-S $\alpha$ subunits $\mathrm{Na}_{\mathrm{v}} 1.7, \mathrm{Na}_{\mathrm{v}} 1.6$, and $\mathrm{Na}_{\mathrm{v}} 1.1$, all normalized to $\alpha$-tubulin as a housekeeping protein loading control, were performed to determine whether the observed changes in mRNA expression were reflected at the level of protein. Changes in mRNA levels are not always reflected by altered protein expression, with $\mathrm{Na}_{\mathrm{v}}-\beta 2$ subunits serving as an example of this phenomenon (Malhotra et al., 2001; Pertin et al., 2005). We observed that $\mathrm{Na}_{\mathrm{v}} 1.1$ and $\mathrm{Na}_{\mathrm{v}} 1.7$ protein levels were reduced in $\beta 2^{-/-}$DRG neurons compared with $\beta 2^{+/+}$, whereas the levels of $\mathrm{Na}_{\mathrm{v}} 1.6$ did not appear to change (Fig. $8 A$ ). Similar results to those shown in the figure were obtained from three or four independent experiments. Immunoreactive bands were normalized to $\alpha$-tubulin by densitometry, and changes in $\beta 2^{-/-}$levels were expressed as a percentage of wild-type levels for each $\mathrm{Na}_{\mathrm{v}} 1$ (Fig. $8 B)$. These calculations showed that $\mathrm{Na}_{\mathrm{v}} 1.1(p=0.082 ; n=3)$ and $\mathrm{Na}_{\mathrm{v}} 1.7(p<0.001 ; n=3)$ were reduced in the null DRGs compared with wild type. The values for $\mathrm{Na}_{\mathrm{v}} 1.6$ were not significantly different $(p=0.23 ; n=4)$. We propose that the observed reduction in mRNA and protein levels of $\mathrm{Na}_{\mathrm{v}} 1.7$ (and possibly the reduction in $\mathrm{Na}_{\mathrm{v}} 1.1$ protein expression) may underlie the reduction in TTX-S $I_{\mathrm{Na}}$ measured in $\beta 2^{-/-}$neurons.

\section{$\beta 2^{-/-}$mice show increased thermal but not mechanical sensitivity}

Because TTX-S $\mathrm{Na}_{\mathrm{v}}$ 1s are involved in nociceptive transmission, we hypothesized that $\beta 2^{-l-}$ mice would exhibit altered responses to noxious stimuli. We showed previously that $\beta 2$ expression is upregulated in sensory neurons in neuropathic pain and that development of mechanical allodynia in the SNI model is attenuated in $\beta 2^{-1-}$ mice compared with wild type (Pertin et al., 2005). To determine whether $\beta 2$ also plays a role in acute pain pathways, we compared the responses of the $\beta 2^{-1-}$ mice to acute thermal and mechanical stimuli with those of their wild-type littermates. In the hot-plate test at $49^{\circ} \mathrm{C}$ (Fig. 9A), $\beta 2^{+/+}$mice exhibited a latency of response of $34.9 \pm 3.0 \mathrm{~s}$. In contrast, $\beta 2^{-\prime-}$ mice displayed a significantly shorter response latency of $27.4 \pm$ $1.5 \mathrm{~s}(p<0.05 ; n=9$ in each group). At higher temperatures, no difference was observed between groups ( $p \geq 0.05$ ). To confirm the hot-plate test results and to determine whether thermal hypersensitivity in $\beta 2^{-1-}$ mice was induced by spinal processes, we evaluated the simple tail-flick reflex response to a radiant heat beam focused on the tail. At a low-intensity setting (4) of the tail-flick analgesia meter (Fig. 9B), the latency was significantly shorter in $\beta 2^{-/-}$mice ( $5.5 \pm 1.1 \mathrm{~s}$ ) compared with $\beta 2^{+/+}$mice $(9.1 \pm 1.2 \mathrm{~s})(p<0.01 ; n=4$ in each group $)$. At a higher intensity (7), a difference between the two groups was not discernible ( $p \geq$ 0.05 ) (Fig. 9B). To investigate whether compensatory upregulation of heat-sensing genes occurred in the $\beta 2^{-1-}$ mice and thus could be responsible for the observed thermal hypersensitivity, we measured the levels of TRPV1 and TRPV2 in DRGs isolated from $\beta 2^{+/+}$and $\beta 2^{-/-}$mice. No differences were detected between the two genotypes (TRPV1: ratio $\beta 2^{-/-} / \beta 2^{+/+}$was 0.95 , $p=0.57$; TRPV2: ratio $\beta 2^{-/-} / \beta 2^{+/+}$was $\left.0.99, p=0.95\right)$.

Mechanical withdrawal threshold responses to a series of cal- 
ibrated monofilaments applied to both paws in both groups were also recorded. Deletion of $\beta 2$ did not modify the animals' response, and we did not observe any significant differences between groups ( $p \geq$ $0.05 ; n=9$ in each group) (Fig. 10). For $\beta 2^{+/+}$mice, the values were $0.246 \pm$ $0.05 \mathrm{~g}$ (left hindpaw) and $0.249 \pm 0.07 \mathrm{~g}$ (right hindpaw) compared with $0.235 \pm$ $0.05 \mathrm{~g}$ (left hindpaw) and $0.283 \pm 0.08 \mathrm{~g}$ (right hindpaw) for $\beta 2^{-/-}$mice.

$\boldsymbol{\beta 2} 2^{-1-}$ mice show reduced response to inflammatory pain

We next performed an extended formalin test to determine the role of $\beta 2$ in this model of acute and inflammatory pain (Tjolsen et al., 1992; Wei et al., 2001). During the initial phase of acute pain, the responses of $\beta 2^{-1-}$ and $\beta 2^{+/+}$mice were similar (Fig. 11). After the initial phase, an early second phase from 10 to $55 \mathrm{~min}$ and a later second phase from 55 to $80 \mathrm{~min}$ have been described previously (Wei et al., 2001). These late phases are considered to be models of inflammatory pain (Tjolsen et al., 1992). During the late phase, the behavioral response of $\beta 2^{-/-}$mice was significantly attenuated when compared with $\beta 2^{+/+}$mice (Fig. 11).

\section{Discussion}

$\mathrm{Na}_{\mathrm{v}} 1 \mathrm{~s}$ in sensory neurons control membrane excitability and contribute to the transmission of nociceptive information to the spinal cord. Both TTX-S and TTX-R $\mathrm{Na}_{\mathrm{v}} 1 \mathrm{~s}$ are expressed in DRG neurons (Baker and Wood, 2001), as are $\beta 1, \beta 1 \mathrm{~A}$, $\beta 2, \beta 3$, and $\beta 4$ (Black et al., 1996; KazenGillespie et al., 2000; Yu et al., 2003). The $\alpha$ subunit cDNAs express functional $\mathrm{Na}_{\mathrm{v}} 1$ in heterologous expression systems. However, for TTX-S $\alpha$ subunits, the currents characteristic of these channels expressed in isolation are quite different from native currents. Coexpression of the $\beta$ subunits with these channels results in shifts in the voltage dependence of activation and inactivation, changes in channel modal gating behavior resulting in increases in the rates of inactivation and recovery from inactivation (Isom et al., 1994), and increases in channel expression at the plasma membrane as assessed by ${ }^{3} \mathrm{H}$ saxitoxin binding (Isom et al., 1995a; Kazarinova-Noyes et al., 2001; McEwen et al., 2004). The $\beta$ subunit-mediated effects on TTX- $\mathrm{R} \mathrm{Na}_{\mathrm{v}} 1$ expressed in heterologous systems are not well understood (Sangameswaran et al., 1996; Malhotra et al., 2001; Vijayaragavan et al., 2001, 2004), and the functional effects of $\mathrm{Na}_{\mathrm{v}} \beta$ subunits on $\alpha$ are dependent on the recipient
A

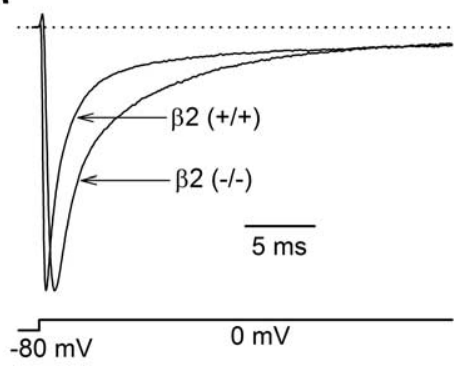

B

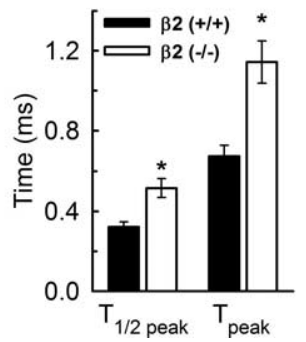

C

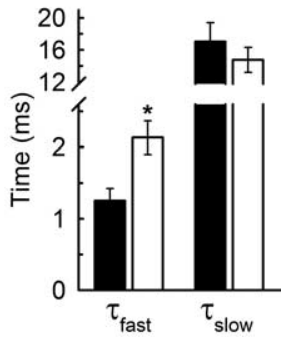

Figure 5. Activation and inactivation kinetics of $I_{\mathrm{Na}}$ at $0 \mathrm{mV}$. $A$, Normalized $I_{\mathrm{Na}}$ evoked by a test pulse to $0 \mathrm{mV}$ from a holding potential of $-80 \mathrm{mV} . I_{\mathrm{Na}}$ are shown from a typical small-fast $\beta 2^{+/+}$cell and a typical small-fast $\beta 2^{-/-}$cell. $\boldsymbol{B}$, Time to achieve 50 and $100 \%$ activation. The data were obtained from small-fast $\beta 2^{+/+}(n=16)$ and small-fast $\beta 2^{-1-}(n=18)$ neurons. $C$ Time constants of $I_{\mathrm{Na}}$ inactivation for the same cells as in $\boldsymbol{B}$. The two time constants of inactivation $\left(\tau_{\text {fast }}\right.$ and $\left.\tau_{\text {slow }}\right)$ were obtained by fitting the decay phase of the $I_{\mathrm{Na}}$ with a double-exponential function. ${ }^{*} p<0.05$, Significantly different from $\beta 2^{+/+}$. Error bars indicate SEM.
A

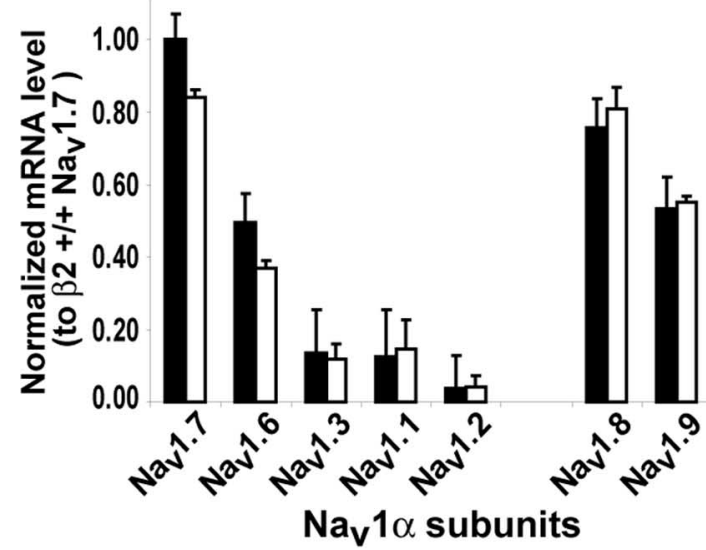

B

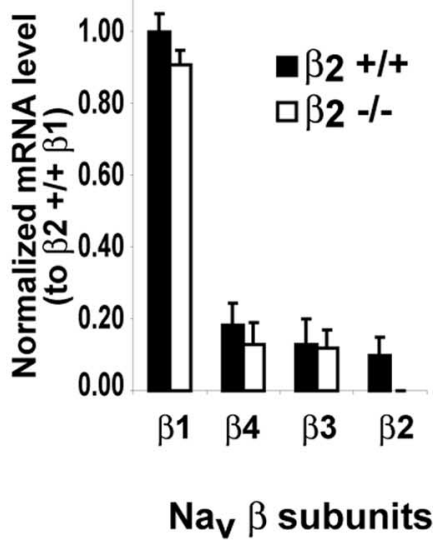

Figure 6. Expression levels of $\mathrm{Na}_{\mathrm{v}} 1 \mathrm{mRNAs}$ in DRGs. $\boldsymbol{A}$, Transcript levels of $\mathrm{Na}_{\mathrm{v}} 1 \alpha$ subunits expressed in $\beta 2^{+/+}$(filled bars) and $\beta 2^{-/-}$(open bars) DRGs; all levels are normalized to $\mathrm{Na}_{\mathrm{v}} 1.7$ levels measured in $\beta 2^{+/+}$DRGs. $\boldsymbol{B}$, Normalized transcript levels of $\beta$ subunits to $\beta 1$ expressed in $\beta 2^{+1+}$ DRGs. Data are mean \pm SEM from a real-time reverse transcription-PCR experiment performed in triplicate using a mix of three samples.
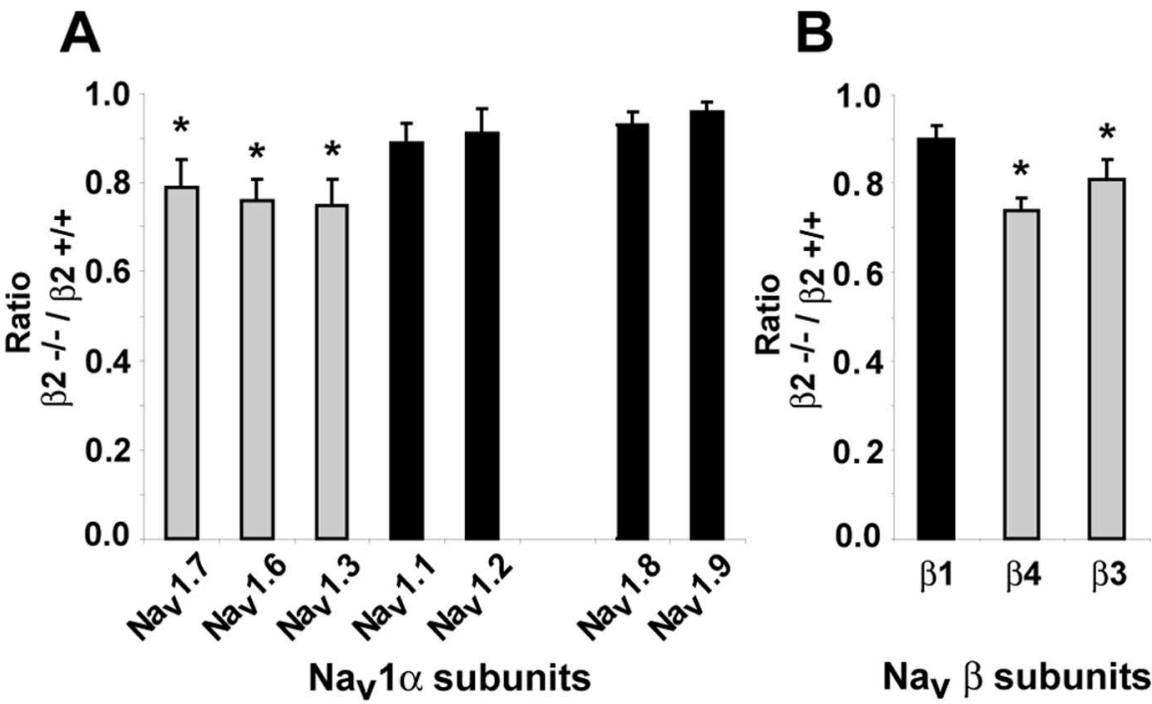

Figure 7. Effect of the $\beta 2$ null mutation on $\mathrm{Na}_{\mathrm{v}} 1 \mathrm{mRNA}$ levels. $A$, Ratio of $\beta 2^{-1-} / \beta 2^{+/+}$transcript levels for $\alpha$ subunit mRNAs. $\boldsymbol{B}$, Ratio of $\beta 2^{-1-} / \beta 2^{+/+}$transcript levels for $\beta$ subunit mRNAs. Black bars, mRNA level does not change; gray bars, mRNA level is reduced. ${ }^{*} p<0.05$. 


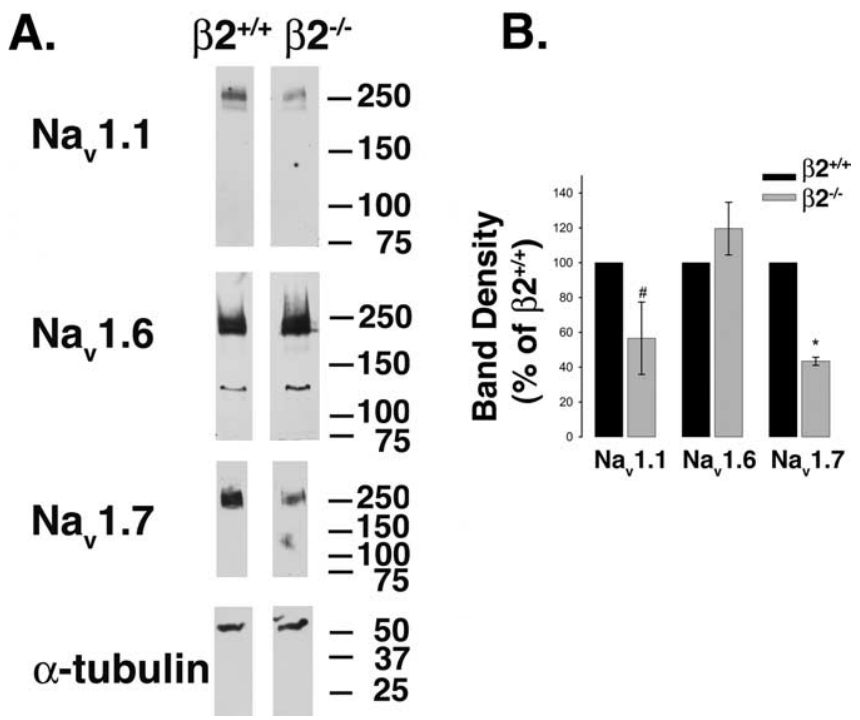

Figure 8. Reduction in $\mathrm{TTX}-\mathrm{S} \mathrm{Na}_{\mathrm{v}} 1$ protein levels in $\beta 2$ null neurons. $A$, Equal aliquots of DRG protein homogenates were separated by SDS-PAGE, transferred to nitrocellulose, and probed with specific $\mathrm{Na}_{\mathrm{v}} 1 \alpha$ subunit antibodies as indicated. All blots were subsequently probed with anti- $\alpha$-tubulin to control for sample loading. The $\alpha$-tubulin blot corresponding to the $\mathrm{Na}_{\mathrm{v}} 1.7$ blot is shown as an example. $\boldsymbol{B}$, Immunoreactive bands were quantified using densitometry. Each band density was first normalized to its corresponding $\alpha$-tubulin signal, and $\beta 2^{-1}$ levels for each $\mathrm{Na}_{\mathrm{v}} 1$ were expressed as a percentage of $\beta 2^{+/+}$levels. For $\mathrm{Na}_{\mathrm{v}} 1.1$ and $\mathrm{Na}_{\mathrm{v}} 1.7$ : ${ }^{\#} p<0.1 ;{ }^{*} p<0.05 ; n=3$. There was no significant change for $\mathrm{Na}_{v} 1.6(n=4)$. Error bars represent SEM.
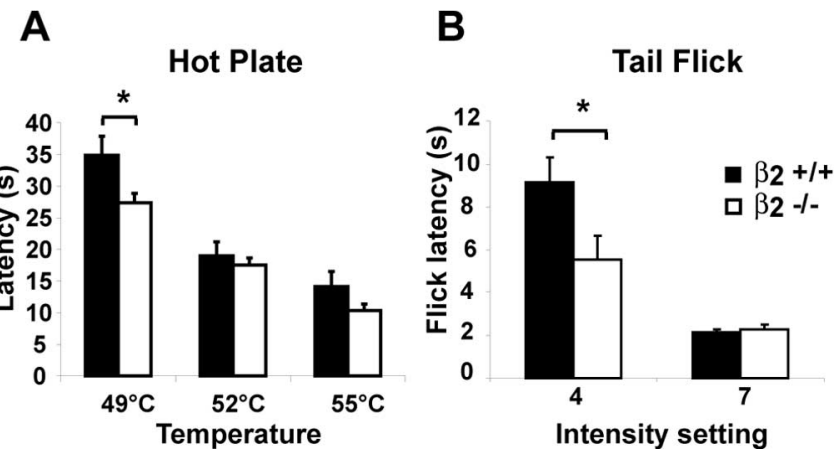

Figure 9. Noxious heat sensitivity. $A$, In the hot-plate test at $49^{\circ} \mathrm{C}$, the latency response was decreased in $\beta 2^{-/-}$mice compared with $\beta 2^{+/+}$animals $\left(n=9\right.$ in each group; ${ }^{*} p<0.05$ ). At higher temperatures $\left(52\right.$ and $\left.55^{\circ} \mathrm{C}\right)$, no statistically significant difference was observable. $\boldsymbol{B}$, Tail-flick test. Values represent the latency response from the heat source. The latency decreased significantly in $\beta 2^{-/-}$mice compared with $\beta 2^{+/+}\left(n=4\right.$ in each group; ${ }^{*} p<$ $0.01)$. No differences were observed at higher intensities. Error bars indicate SEM.

cell type in vitro (Chen et al., 2002; Meadows and Isom, 2005). Thus, the use of in vivo models is critical to the understanding of their physiological roles. The present studies using $\beta 2$ null mice make important and novel contributions to elucidating the function of $\beta 2$ in electrical signal transduction in sensory neurons and are the first report of the differential effects of $\beta 2$ on TTX-S versus TTX-R channels.

In the present study, we compared $I_{\mathrm{Na}}$ in DRG neurons isolated from $\beta 2^{+/+}$and $\beta 2^{-1-}$ mice to determine the effects of $\beta 2$ on TTX-S and TTX-R Na 1 s in vivo. Small-fast DRG neurons acutely isolated from $\beta 2^{-1-}$ mice showed significant decreases in TTX-S but not TTX-R $I_{\mathrm{Na}}$ compared with DRG neurons isolated from wild-type littermates. This decrease was not a result of changes in the voltage dependence of activation or inactivation of TTX-S $\mathrm{Na}_{\mathrm{v}} 1 \mathrm{~s}$. TTX-S, but not TTX-R, $I_{\mathrm{Na}}$ activation and inacti-

\section{Mechanical sensitivity}

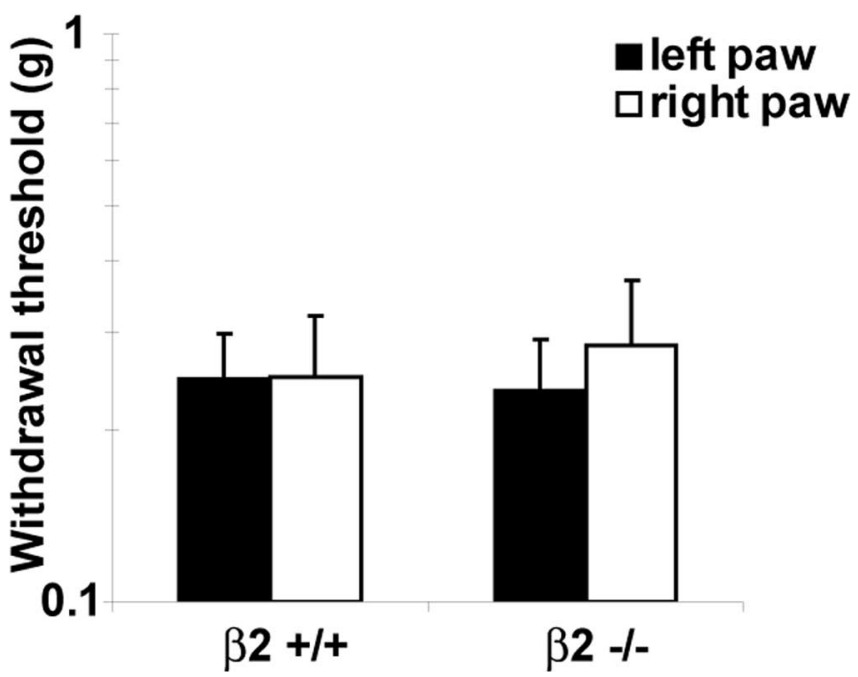

Figure 10. Basal mechanical sensitivity. Withdrawal mechanical thresholds were similar in $\beta 2^{+/+}$and $\beta 2^{-/-}$animals $(n=9$ in each group; $p>0.05)$. Error bars indicate SEM.

vation kinetics in small-fast DRG neurons were significantly slower in $\beta 2^{-/-}$mice compared with $\beta 2^{+/+}$. Our results predict that $\beta 2$ expression results in increased levels of TTX-S $\mathrm{Na}_{\mathrm{v}} 1$ mRNA and protein expression, particularly $\mathrm{Na}_{\mathrm{v}} 1.7$, increased levels of TTX-S $\mathrm{Na}_{\mathrm{v}} 1$ cell-surface expression, and increased rates of TTX-S $I_{\mathrm{Na}}$ activation and inactivation in small-fast DRG neurons in vivo. TTX-R $I_{\mathrm{Na}}$ in small-slow and small-fast DRG neurons are insensitive to modulation by $\beta 2$.

Interestingly, the $\beta 2$ null mutation affects TTX-S $I_{\mathrm{Na}}$ in smallslow versus small-fast DRG neurons differently. TTX-S $I_{\mathrm{Na}}$ are dramatically reduced in small-fast neurons but are essentially unaffected in small-slow neurons. A possible explanation for this observation is that small-slow and small-fast DRG neurons may express vastly different levels of $\beta 2$ protein. Alternatively, perhaps these two neuronal populations express different profiles of TTX-S $\mathrm{Na}_{\mathrm{v}} 1 \mathrm{~s}$ that are differentially regulated by $\beta 2$ in vivo. Previously, we reported that $\beta 2$ protein expression is low in normal DRG neurons, although immunocytochemical staining could be detected in small, medium, and large cells (Pertin et al., 2005). Unfortunately, this low level of $\beta 2$ staining precluded our ability to perform a more complete analysis of differential expression in small neurons in the present study. Because $\beta 2$ mRNA levels are poor predictors of $\beta 2$ protein levels (Malhotra et al., 2001; Pertin et al., 2005) and because evidence suggests that posttranscriptional regulation of $\beta 2$ may be critical to $\beta 2$ protein expression in the DRG (Pertin et al., 2005), single-cell RT-PCR experiments would not be helpful in understanding the relative levels of $\beta 2$ peptides in small-slow versus small-fast cells. Until a more sensitive antibody can be developed, this issue will be difficult to address. Nevertheless, it is intriguing to consider that, as reported recently by the Waxman group (Rush et al., 2006), ion channel mutations can have opposing physiological effects in various neuronal cell types as a result of cell background differences, including different repertoires of ion channels within the two type of neurons.

$\mathrm{Na}_{\mathrm{v}} 1 \mathrm{~s}$ play a major role in pain through determination of membrane excitability in central and peripheral neurons. The threshold for repetitive firing of sensory neurons, and thus ectopic activity, is primarily determined by the density of $\mathrm{Na}_{\mathrm{v}} 1 \mathrm{~s}$ in 
A
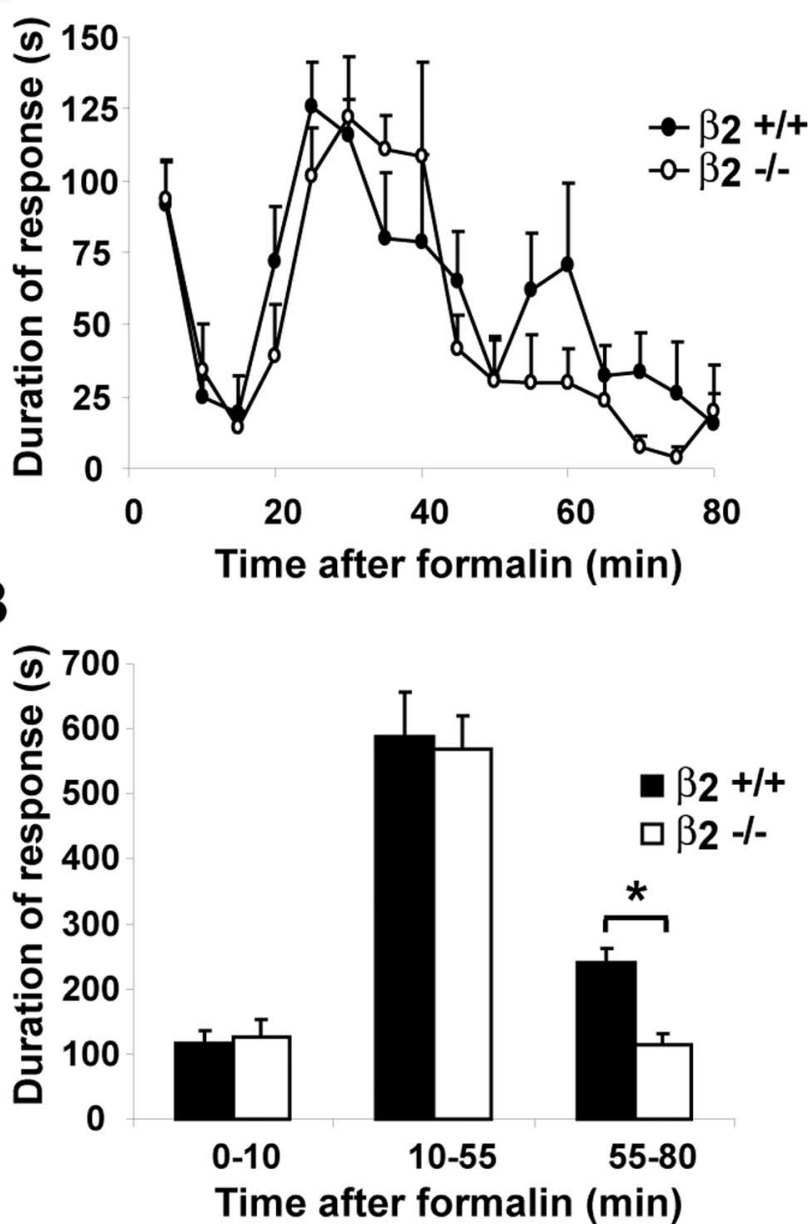

Figure 11. Formalin test. $A$, Time course of the formalin response after intraplantar injection of $10 \mu \mathrm{l}$ of $5 \%$ formalin. $\boldsymbol{B}$, Cumulative formalin response to the initial phase $(0-10 \mathrm{~min})$, early second phase $(10-55 \mathrm{~min})$, and late second phase $(55-80 \mathrm{~min}) . \beta 2^{+/+}$, filled bars or symbols; $\beta 2^{-1-}$, open bars or symbols. $n=6$ per group; ${ }^{*} p<0.05$. Error bars indicate SEM.

the plasma membrane. If excitability is suppressed (e.g., by a reduction in cell-surface $\mathrm{Na}_{\mathrm{v}} 1$ s below a certain threshold level), the neuron can no longer respond to depolarizing stimuli by generating pacemaker activity (Devor, 2006). TTX-S Na 1 s play roles in inflammatory, visceral, and neuropathic pain. This has been directly demonstrated by administration of low doses of TTX locally to DRGs (Lyu et al., 2000) or systemically (Marcil et al., 2006) in rodents. According to these studies, nanomolar doses of TTX decrease pain behavior in the late inflammatory (but not early acute) phase of the formalin test, in the writhing test of visceral pain, in mechanical allodynia in the Chung model of neuropathic pain (Kim and Chung, 1992), and in mechanical allodynia and thermal hyperalgesia in the Seltzer model of neuropathic pain (Seltzer et al., 1990). TTX administered at these low doses had no detectable effects on action potential conduction despite exerting significant behavioral effects. Thus, we predicted that $\beta 2^{-1-}$ mice, which have an $\sim 50 \%$ reduction in expression of TTX-S $I_{\mathrm{Na}}$ in small-fast DRG neurons, would have reduced levels of firing in response to depolarizing stimuli and thus reduced inflammatory and neuropathic pain responses with little effect on action potential propagation, similar to the effects of local anesthetic, membrane-stabilizing drugs (Devor, 2006). Indeed, the allodynic response to the SNI model of neuropathic pain was reduced in $\beta 2^{-1-}$ mice, although basal mechanical sensitivity was not altered before nerve injury (Pertin et al., 2005). The behavior of $\beta 2^{-1-}$ mice in the early acute phase of the formalin test was not different from wild-type animals; however, the response of these mice to the late, inflammatory phase was attenuated, consistent with the TTX experiments and similar to results in $\mathrm{Na}_{\mathrm{v}} 1.7$ null mice (Nassar et al., 2004). Action potential conduction velocity remains intact in $\beta 2^{-1-}$ mice (Chen et al., 2002), consistent with the reported effects of nanomolar TTX. The response to low-threshold mechanical stimulation with von Frey hairs was not affected by the $\beta 2$ null mutation. These results are consistent with the observation that TTX does not block mechanically activated currents in sensory neurons (Drew et al., 2004) and that $\mathrm{Na}_{\mathrm{v}} 1.7$ null mice show no differences in their response to von Frey hairs (Nassar et al., 2004).

An unexpected finding in our study was a normal thermal sensitivity of $\beta 2^{-1-}$ mice at high temperatures $\left(52-55^{\circ} \mathrm{C}\right)$, whereas at a lower temperature $\left(49^{\circ} \mathrm{C}\right), \beta 2^{-1-}$ mice displayed relative heat hypersensitivity in the hot-plate test. Similarly, in the tail-flick test, $\beta 2^{-1-}$ mice were more responsive to low-intensity stimulation. RT-PCR experiments showed that this response was not attributable to compensatory upregulation of TRPV1 or TRPV2 in the null DRGs, although we cannot rule out other genes involved in thermal sensation. Heat sensing involves thermal C- and A-fiber nociceptors, with a distribution of the highthreshold $\left(52^{\circ} \mathrm{C}\right)$ TRPV2 sensor in larger DRG neurons (Greffrath et al., 2003; Patapoutian et al., 2003; Shimosato et al., 2005). It is thus possible that in this very subset of DRG neurons, the expression of $\mathrm{Na}_{\mathrm{v}} 1 \mathrm{~s}$ is different and the deletion of $\beta 2$ may alter proprieties and produce a hyperexcitable phenotype for lowerthreshold nociceptors (Rush et al., 2006). On the other hand, the hyperexcitable phenotype may be related to central alteration of pain signaling. Experiments in cats have demonstrated that the dominant effect of noxious heat on dorsal horn interneurons is inhibitory (Schomburg et al., 2000). For instance, one may suggest that spinal interneurons in the null animals present reduced cell-surface TTX-S Na 1 expression and thus reduced excitability. However, because nociception ultimately involves peripheral and central neurons in ascending and descending pathways, the ultimate answer to this question must wait for the future development of tissue-specific $\beta 2$ null mice that will allow the study of $\beta 2$ subunits in individual neuronal populations.

We propose that the major functional role of $\mathrm{Na}_{\mathrm{v}} \beta 2$ subunits in vivo is to regulate TTX-S $\mathrm{Na}_{\mathrm{v}} 1 \alpha$ subunit insertion into the plasma membrane in both CNS and PNS neurons, thus critically regulating neuronal excitability. $\beta 2^{-I-}$ mice, under homeostatic conditions, are able to maintain normal patterns of neuronal firing. However, in models of inflammatory or neuropathic pain, in which induction of peripheral firing and central sensitization are required, our results suggest the density of plasma membrane $\mathrm{Na}_{\mathrm{v}} 1$ is insufficient and peripheral bursts can neither be evoked nor maintained.

\section{References}

Abdulla FA, Smith PA (2001) Axotomy- and autotomy-induced changes in $\mathrm{Ca} 2+$ and $\mathrm{K}+$ channel currents of rat dorsal root ganglion neurons. J Neurophysiol 85:644-658.

Abdulla FA, Smith PA (2002) Changes in $\mathrm{Na}(+)$ channel currents of rat dorsal root ganglion neurons following axotomy and axotomy-induced autotomy. J Neurophysiol 88:2518-2529.

Akopian AN, Sivilotti L, Wood JN (1996) A tetrodotoxin-resistant voltagegated sodium channel expressed by sensory neurons. Nature 379:257-262.

Akopian AN, Souslova V, England S, Okuse K, Ogata N, Ure J, Smith A, Kerr 
BJ, McMahon SB, Boyce S, Hill R, Stanfa LC, Dickenson AH, Wood JN (1999) The tetrodotoxin-resistant sodium channel SNS has a specialized function in pain pathways. Nat Neurosci 2:541-548.

Armstrong C, Bezanilla F (1977) Inactivation of the sodium channel. II. Gating current experiments. J Gen Physiol 70:567-590.

Baker MD, Wood JN (2001) Involvement of $\mathrm{Na}+$ channels in pain pathways. Trends Pharmacol Sci 22:27-31.

Black JA, Dib-Hajj S, McNabola K, Jeste S, Rizzo MA, Kocsis JD, Waxman SG (1996) Spinal sensory neurons express multiple sodium channel alphasubunit mRNAs. Brain Res Mol Brain Res 43:117-131.

Cao YQ, Mantyh PW, Carlson EJ, Gillespie AM, Epstein CJ, Basbaum AI (1998) Primary afferent tachykinins are required to experience moderate to intense pain. Nature 392:390-394.

Catterall WA (2000) From ionic currents to molecular mechanisms: the structure and function of voltage-gated sodium channels. Neuron 26:13-25.

Chen C, Bharucha B, Chen Y, Westenbroek RE, Brown A, Malhotra JD, Jones D, Avery C, Gillespie III PJ, Kazen-Gillespie KA, Saunders TL, Macdonald RL, Ransom B, Scheuer T, Catterall WA, Isom LL (2002) Reduced sodium channel density, altered voltage dependence of inactivation, and increased susceptibility to seizures in mice lacking sodium channel $\beta 2$ subunits. Proc Natl Acad Sci USA 99:17072-17077.

Cummins TR, Waxman SG (1997) Downregulation of tetrodotoxinresistant sodium currents and upregulation of a rapidly repriming tetrodotoxin-sensitive sodium current in small spinal sensory neurons after nerve injury. J Neurosci 17:3503-3514.

Devor M (2006) Sodium channels and mechanisms of neuropathic pain. J Pain 7:S3-S12.

Dib-Hajj S, Black JA, Cummins TR, Waxman SG (2002) NaN/Nav1.9: a sodium channel with unique properties. Trends Neurosci 25:253-259.

Drew LJ, Rohrer DK, Price MP, Blaver KE, Cockayne DA, Cesare P, Wood JN (2004) Acid-sensing ion channels ASIC2 and ASIC3 do not contribute to mechanically activated currents in mammalian sensory neurones. J Physiol (Lond) 556:691-710.

Flake NM, Lancaster E, Weinreich D, Gold MS (2004) Absence of an association between axotomy-induced changes in sodium currents and excitability in DRG neurons from the adult rat. Pain 109:471-480.

Goldin AL (1993) Accessory subunits and sodium channel inactivation. Curr Opin Neurobiol 3:272-277.

Greffrath W, Binzen U, Schwarz ST, Saaler-Reinhardt S, Treede RD (2003) Co-expression of heat sensitive vanilloid receptor subtypes in rat dorsal root ganglion neurons. NeuroReport 14:2251-2255.

Hamill OP, Marty A, Neher E, Sakmann B, Sigworth FJ (1981) Improved patch-clamp techniques for high-resolution current recording from cells and cell-free membrane patches. Pflügers Arch 391:85-100.

Hille B (2001) Ion channels of excitable membranes, Ed 3. Sunderland, MA: Sinauer Associates.

Isom LL (2000) Pathobiology of visceral pain: molecular mechanisms and therapeutic implications, I. Cellular and molecular biology of sodium channel $\beta$-subunits: therapeutic implications for pain? Am J Physiol Gastrointest Liver Physiol 278:G349-G353.

Isom LL, De Jongh KS, Catterall WA (1994) Auxiliary subunits of voltagegated ion channels. Neuron 12:1183-1194.

Isom LL, Scheuer T, Brownstein AB, Ragsdale DS, Murphy BJ, Catterall WA (1995a) Functional co-expression of the $\beta 1$ and type IIA $\alpha$ subunits of sodium channels in a mammalian cell line. J Biol Chem 270:3306-3312.

Isom LL, Ragsdale DS, De Jongh KS, Westenbroek RE, Reber BF, Scheuer T, Catterall WA (1995b) Structure and function of the $\beta 2$ subunit of brain sodium channels, a transmembrane glycoprotein with a CAM motif. Cell 83:433-442.

Kazarinova-Noyes K, Malhotra JD, McEwen DP, Mattei LN, Berglund EO, Ranscht B, Levinson SR, Schachner M, Shrager P, Isom LL, Xiao Z-C (2001) Contactin associates with $\mathrm{Na}^{+}$channels and increases their functional expression. J Neurosci 21:7517-7525.

Kazen-Gillespie KA, Ragsdale DS, D’Andrea MR, Mattei LN, Rogers KE, Isom LL (2000) Cloning, localization, and functional expression of sodium channel $\beta 1$ A subunits. J Biol Chem 275:1079-1088.

Kim SH, Chung JM (1992) An experimental model for peripheral neuropathy produced by segmental spinal nerve ligation in the rat. Pain 50:355363.

Lyu YS, Park SK, Chung K, Chung JM (2000) Low dose of tetrodotoxin reduces neuropathic pain behaviors in an animal model. Brain Res 871:98-103.

Malhotra JD, Kazen-Gillespie K, Hortsch M, Isom LL (2000) Sodium channel $\beta$ subunits mediate homophilic cell adhesion and recruit ankyrin to points of cell-cell contact. J Biol Chem 275:11383-11388.

Malhotra JD, Chen C, Rivolta I, Abriel H, Malhotra R, Mattei LN, Brosius FC, Kass RS, Isom LL (2001) Characterization of sodium channel $\alpha$ and $\beta$ subunits in rat and mouse cardiac myocytes. Circulation 103:1303-1310.

Marcil J, Walczak JS, Guindon J, Ngoc AH, Lu S, Beaulieu P (2006) Antinociceptive effects of tetrodotoxin (TTX) in rodents. $\mathrm{Br} \mathrm{J}$ Anaesth 96:761-768.

McEwen DP, Meadows LS, Chen C, Thyagarajan V, Isom LL (2004) Sodium channel $\beta 1$ subunit-mediated modulation of Nav1.2 currents and cell surface density is dependent on interactions with contactin and ankyrin. J Biol Chem 279:16044-16049.

Meadows LS, Isom LL (2005) Sodium channels as macromolecular complexes: implications for inherited arrhythmia syndromes. Cardiovasc Res 67:448-458.

Meza U, Avila G, Felix R, Gomora JC, Cota G (1994) Long-term regulation of calcium channels in clonal pituitary cells by epidermal growth factor, insulin, and glucocorticoids. J Gen Physiol 104:1019-1038.

Nassar MA, Stirling LC, Forlani G, Baker MD, Matthews EA, Dickenson AH, Wood JN (2004) Nociceptor-specific gene deletion reveals a major role for Nav1.7 (PN1) in acute and inflammatory pain. Proc Natl Acad Sci USA 101:12706-12711.

Patapoutian A, Peier AM, Story GM, Viswanath V (2003) ThermoTRP channels and beyond: mechanisms of temperature sensation. Nat Rev Neurosci 4:529-539.

Pertin M, Ji RR, Berta T, Powell AJ, Karchewski L, Tate SN, Isom LL, Woolf CJ, Gilliard N, Spahn DR, Decosterd I (2005a) Upregulation of the voltage-gated sodium channel $\beta 2$ subunit in neuropathic pain models: characterization of expression in injured and non-injured primary sensory neurons. J Neurosci 25:10970-10980.

Pfaffl MW (2001) A new mathematical model for relative quantification in real-time RT-PCR. Nucleic Acids Res 29:e45.

Ratcliffe CF, Qu Y, McCormick KA, Tibbs VC, Dixon JE, Scheuer T, Catterall WA (2000) A sodium channel signaling complex: modulation by associated receptor protein tyrosine phosphatase $\beta$. Nat Neurosci 3:437-444.

Ratcliffe CF, Westenbrook RE, Curtis R, Catterall WA (2001) Sodium channel $\beta 1$ and $\beta 3$ subunits associate with neurofascin through their extracellular immunoglobulin-like domain. J Cell Biol 154:427-434.

Roy ML, Narahashi T (1992) Differential properties of tetrodotoxinsensitive and tetrodotoxin-resistant sodium channels in rat dorsal root ganglion neurons. J Neurosci 12:2104-2111.

Rush AM, Brau ME, Elliott AA, Elliott JR (1998) Electrophysiological properties of sodium current subtypes in small cells from adult rat dorsal root ganglia. J Physiol (Lond) 511:771-789.

Rush AM, Dib-Hajj SD, Liu S, Cummins TR, Black JA, Waxman SG (2006) A single sodium channel mutation produces hyper- or hypoexcitability in different types of neurons. Proc Natl Acad Sci USA 103:8245-8250.

Sangameswaran L, Delgado SG, Fish LM, Koch BD, Jakeman LB, Stewart GR, Sze P, Hunter JC, Eglen RM, Herman RC (1996) Structure and function of a novel voltage-gated, tetrodotoxin-resistant sodium channel specific to sensory neurons. J Biol Chem 271:5953-5956.

Schmidt J, Rossie S, Catterall WA (1985) A large intracellular pool of inactive $\mathrm{Na}^{+}$channel alpha subunits in developing rat brain. Proc Natl Acad Sci USA 82:4847-4851.

Schmidt JW, Catterall WA (1986) Biosynthesis and processing of the alpha subunit of the voltage-sensitive sodium channel in rat brain neurons. Cell 46:437-445.

Schomburg ED, Jankowska E, Wiklund Fernstrom K (2000) Nociceptive input to spinal interneurones in reflex pathways from group II muscle afferents in cats. Neurosci Res 38:447-450.

Seltzer Z, Dubner R, Shir Y (1990) A novel behavioral model of neuropathic pain disorders produced in rats by partial sciatic nerve injury. Pain 43 : $205-218$.

Shimosato G, Amaya F, Ueda M, Tanaka Y, Decosterd I, Tanaka M (2005) Peripheral inflammation induces up-regulation of TRPV2 expression in rat DRG. Pain 119:225-232.

Srinivasan J, Schachner M, Catterall WA (1998) Interaction of voltagegated sodium channels with the extracellular matrix molecules tenascin-C and tenascin-R. Proc Natl Acad Sci USA 95:15753-15757. 
Srinivasan Y, Elmer L, Davis J, Bennett V, Angelides K (1988) Ankyrin and spectrin associate with voltage-dependent sodium channels in brain. Nature 333:177-180.

Study RE, Kral MG (1996) Spontaneous action potential activity in isolated dorsal root ganglion neurons from rats with a painful neuropathy. Pain 65:235-242.

Suter MR, Papaloizos M, Berde CB, Woolf CJ, Gilliard N, Spahn DR, Decosterd I (2003) Development of neuropathic pain in the rat spared nerve injury model is not prevented by a peripheral nerve block. Anesthesiology 99:1402-1408.

Swett JE, Torigoe Y, Elie VR, Bourassa CM, Miller PG (1991) Sensory neurons of the rat sciatic nerve. Exp Neurol 114:82-103.

Tjolsen A, Berge OG, Hunskaar S, Rosland JH, Hole K (1992) The formalin test: an evaluation of the method. Pain 51:5-17.

Vandesompele J, De Paepe A, Speleman F (2002) Elimination of primerdimer artifacts and genomic coamplification using a two-step SYBR green I real-time RT-PCR. Anal Biochem 303:95-98.

Vijayaragavan K, O'Leary ME, Chahine M (2001) Gating properties of
$\mathrm{Na}_{\mathrm{v}} 1.7$ and $\mathrm{Na}_{\mathrm{v}} 1.8$ peripheral nerve sodium channels. J Neurosci 21:7909-7918.

Vijayaragavan K, Powell AJ, Kinghorn IJ, Chahine M (2004) Role of auxiliary beta1-, beta2-, and beta3-subunits and their interaction with $\mathrm{Na}(\mathrm{v}) 1.8$ voltage-gated sodium channel. Biochem Biophys Res Commun 319:531-540.

Wei F, Wang GD, Kerchner GA, Kim SJ, Xu HM, Chen ZF, Zhuo M (2001) Genetic enhancement of inflammatory pain by forebrain NR2B overexpression. Nat Neurosci 4:164-169.

Wilson SG, Mogil JS (2001) Measuring pain in the (knockout) mouse: big challenges in a small mammal. Behav Brain Res 125:65-73.

Xiao Z-C, Ragsdale DS, Malhotra JD, Mattei LN, Braun PE, Schachner M, Isom LL (1999) Tenascin-R is a functional modulator of sodium channel $\beta$ subunits. J Biol Chem 274:26511-26517.

Yu FH, Westenbroek RE, Silos-Santiago I, McCormick KA, Lawson D, Ge P, Ferriera H, Lilly J, DiStefano PS, Catterall WA, Scheuer T, Curtis R (2003) Sodium channel $\beta 4$, a new disulfide-linked auxiliary subunit with similarity to $\beta 2$. J Neurosci 23:7577-7585. 